\title{
Cracking the fault line in stock markets: the case of bonus issue announcements
}

\author{
Murat Isiker \\ Managament, Istanbul Sabahattin Zaim University, Istanbul, Turkey, and \\ Oktay Tas \\ Faculty of Management, Istanbul Technical University, Istanbul, Turkey
}

Cracking the fault line in stock markets

Received 29 March 2021 Revised 26 May 2021 Accepted 1 July 2021

\begin{abstract}
Purpose - The paper aims to measure the magnitude of the event-induced return anomaly around bonus issue announcement days in Turkey for recent years. Also, by describing the information content of these announcements with the current data, the study tries to find out the factors that cause return anomaly in Borsa Istanbul when firm boards release the bonus issue decision.

Design/methodology/approach - The paper conducts event study methodology for detecting market anomaly around bonus issue announcements. For the pairwise comparison purpose, $t$-test and one-way ANOVA methods are applied to examine if abnormal returns vary according to the information content of the announcements.

Findings - Announcement returns for bonus issues from internal resources outperform the issues that are distributed from last year's net income as bonus shares. Findings indicate different return behaviour among internal resources sub-groups. Findings also suggest that investors in Turkey welcome larger-sized issues, while cumulated returns for the initial offers significantly differ from the latter issues.

Research limitations/implications - Findings are limited to the Turkish equity market. Also, the Public Disclosure Platform of Turkey, which is the main data source of the study, does not provide bonus issue announcements before 2010. Therefore, the previous year's data cannot be included in the analysis.

Originality/value - This paper is novel in terms of considering the main resources of the bonus issue in detail to measure the announcement's impact on stock returns.
\end{abstract}

Keywords Bonus issue, Announcement effect, Stock dividend, Market sentiment, Borsa Istanbul, Event study Paper type Research paper

\section{Introduction and literature review}

Bonus issue and its' effect on stock returns is a phenomenon in the finance literature, especially for developing markets [1]. A bonus issue is described as nothing but a "cosmetic amendment" within the owner's equity statement (Dhar and Chhaochharia, 2008; Kalay and Zhang, 2019). More precisely, some portion of funds that are accumulated in years in retained earnings, capital and income reserves are transferred to the paid-in capital. Fama (1970) states that there should be no chance to beat the market in the strong form of the efficient market hypothesis $(\mathrm{EMH})$ as the price of a security reflects all publicly and privately available information. Since all of these accounts belong to the equity statement, it means that the capital increase occurs within this part.

On 16 October 2020, Kartonsan A.S (with the ticker code KARTN), quoted in Borsa Istanbul (BIST), announced increasing its paid-in capital by $2543.62 \%$ via bonus issue using

(C) Murat Isiker and Oktay Tas. Published in Journal of Capital Markets Studies. Published by Emerald Publishing Limited. This article is published under the Creative Commons Attribution (CC BY 4.0) license. Anyone may reproduce, distribute, translate and create derivative works of this article (for both commercial and non-commercial purposes), subject to full attribution to the original publication and authors. The full terms of this license may be seen at http://creativecommons.org/licences/by/4.0/ legalcode

This paper is based on the $\mathrm{PhD}$ thesis of Murat Isiker.

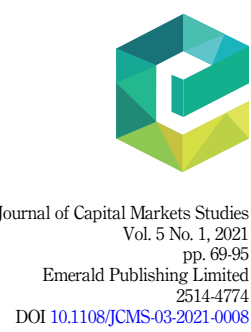


JCMS 5,1 the company's internal resources. The size of the bonus issue in percentage is detected as one of the largest in recent years. The pre-announcement closing price for the company was 769 TRY per share, while the post-announcement ten days cumulative return calculated as $159 \%$. This announcement also affected the share prices of other companies, in which investors expect to hear a similar announcement for many years [2]. The common characteristic of these companies is that being traded at high share prices, which implies that paid-in capital is dramatically low compared to other equity accounts. Although a bonus issue announcement does not carry new information, it is expected not to affect the market value of a company in theory. Thus, why does generally price increase occur after bonus issue announcements?

Baker and Phillips (1993) present a survey result for the US market, which suggests that more than $90 \%$ of firm managers confirm the positive psychological effect of bonus shares distribution on investors. However, the literature provides other possible explanations for the favourable market reaction. Signalling is the primary argument for this behaviour. The intuition is that in an environment of information asymmetry, managers use bonus share distribution to provide a signal to investors about the firm's potential operational growth. (Lakonishok and Lev, 1987; Rankine and Stice, 1997). Mixed results are documented in some emerging markets regarding profitability change around issue periods. (Lukose and Sapar, 2002; Anderson et al., 2011; Al-Yahyaee, 2014). Moreover, the cash substitution hypothesis suggests that firms may prefer bonus share distribution instead of cash dividends if they are optimistic for future growth (Kalay and Zhang, 2019). However, Feito-Ruiz et al. (2020) suggest that financially constrained firms mostly apply optional bonus share distributions to satisfy upcoming debt payment. David and Ginglinger (2016) also claim probability of bonus distribution increases during economic downturns or when the leverage level of firms increases. Finally, demand increase to the shares of bonus issuing firms can cause a positive market reaction. The trading range hypothesis asserts that managers apply bonus issues to bring the stock price to a more reasonable level, which expands the investor base and hence increase the liquidity (Lakonishok and Lev, 1987; Schultz, 2000; Huang et al., 2009).

There are three main purposes of this study. First, the paper aims to measure the magnitude of the event-induced return anomaly around bonus issue announcement days in Turkey in recent years. Findings will help to discuss the market efficiency level in BIST for the last decade, which is the study period of the paper. Second, by describing the information content of these announcements, the paper aims to identify the factors that cause return anomaly in Turkey when firm boards release a bonus issue decision. Third, after determining which factors trigger abnormal returns, the study aims to state policy recommendations to the regulatory body that can help to reduce market inefficiency.

The announcement effect of bonus issues in Turkey is examined in the literature. Aydogan and Muradoglu (1998) investigate this topic for the early stages of BIST (formerly Istanbul Stock Exchange) from 1988 to 1993 . This paper analyses the efficiency of the market to understand how anomaly during bonus issue announcements is shaped for different subperiods. Also, Adaoglu and Lasfer (2011) cover years from 1995 to 2006 to measure the market anomaly and its possible determinants. Despite both studies document significant pre- and post-event market anomaly in general, the first paper asserts that abnormal returns around announcement days vanish for 1991-1993. Authors associate this finding with market maturity along with an improvement in market efficiency. On the other hand, Batchelor and Orakcioglu (2003) focus on the return volatility around the ex-date of bonus issues. The authors find insignificant abnormal returns around the ex-dividend days while a huge volatility increase is detected. The paper assumes that uninformed investors who fail to estimate true post-split price cause this behaviour.

Apart from Turkey, the bonus issue announcement effect has also been examined for developed and developing markets. Early studies in the US provide evidence regarding detecting positive abnormal returns around stock dividend announcements (Grinblatt et al., 
1984; McNichols and Dravid, 1990). However, recent studies indicate that market anomaly is no longer observed in the US (Khanal and Misra, 2017; Kalay and Zhang, 2019). Improving market efficiency can be attributed to this change. Also, in other developed markets such as Australia, Denmark, Germany and Japan, positive abnormal returns are detected. (Balachandran and Tanner, 2001; Bechmann and Raaballe, 2007; Wulff, 2002; Kato and Tsay, 2002). Likewise developed market cases, most of the papers document positive abnormal return around announcement days for developing markets such as China, Egypt, India, Nigeria and Sri Lanka (Nguyen and Wang, 2013; El Ansary and Hussein, 2017; Raja and Sudhahar, 2010; Campbell and Ohuocha, 2011; Pathirawasam, 2009).

This paper is novel in terms of considering the main resources of the bonus issue in detail. As the second section describes, announcements are categorised according to issue sources and analysed separately. The paper also investigates the effect of bonus distribution size, which is described as a key determinant of market reaction by the papers such as Balachandran and Tanner (2001) and Adaoglu and Lasfer (2011). A higher abnormal return is expected for the higher issues. The intuition behind this idea is that the larger issues carry more information, which can signify future growth potential. Mateus et al. (2017) assert that sectoral distinction is critical when analysing the announcement effect for capital increase events since capital adequacy is strictly controlled by regulatory bodies for financial firms. It is assumed that the results for financial and non-financial firms may vary. Mian and Sankaraguruswamy (2012) argue that market trends affect the magnitude of price movements during surprise earning announcements. In this study, bullish and bearish market conditions are examined around bonus issue announcements.

Last but not least, the returns for the initial and latter bonus issues are compared. Kalay and Zhang (2019) document that the latter bonus issues are perceived as less favourable compared to the initial ones in the US market. Finally, market reactions for expected and surprise bonus distribution announcements are examined. Bonus issues are grouped according to the months in which the initial announcement is made. The majority of the announcements occur between February and May, in which annual earnings are announced and general assembly meetings are held. Thus, an announcement is named "expected" if it becomes publicly available within these months, and it is categorised as "surprise" if it is not. This section is the novel part for bonus issue studies and intuitively assumes that market reaction can be different for the groups mentioned above.

This study is also distinguished from previous studies by covering the periods where Turkey's annual inflation rate was relatively higher. Average annual inflation rates for the study periods in Aydogan and Muradoglu (1998) and Adaoglu and Lasfer (2011) are calculated as 68 and $48 \%$, respectively, while it is found as $10 \%$ for the study period. Since adjustment on equity accounts were applied until 2005 in Turkey due to a highly inflationary environment, it is assumed that market reaction to bonus issue announcements may differ from previous studies. Thus, this paper also contributes to the literature in Turkey by dealing with the current data.

The remaining parts are organised as follows: the second section describes the data used in the study and explains the institutional background in Turkey briefly. Methods are specified in the third section, while findings are represented in the fourth section. Finally, the fifth section concludes the paper and includes policy implications derived from the findings.

\section{Data and institutional background}

The sample consists of companies listed in BIST that announce capital increase via bonus issue between 2010 and 2019. The main source of collecting announcement dates is the Public Disclosure Platform of Turkey (PDP), known in short as " $K A P$ " in Turkey. The system was established through Communiqué Serial Number VII-128.6 by the Central Securities Depository of Turkey (CSD) and became available in 2010 after a transitional period in 2009.

Cracking the fault line in stock markets 
JCMS 5,1

\section{2}

The platform allows investors to reach firm-specific notifications as soon as the firms or regulatory bodies release them. However, firm-related reports or analyses that brokerage houses or investment companies publish are not available on this platform.

The hand-collected data are used for the study, and for validity purpose, the event dates are compared with the data retrieved from the Thomson Reuters Eikon database under the section of corporate events with the name of "scrip issue". Some differences are detected between the two datasets. First, Eikon includes combined events such as rights issue simultaneous with bonus issue. These events are excluded from the dataset since many studies document that rights issue announcements are perceived as negative news (Balachandran et al., 2012; Kim and Song, 2020; Isiker and Tas, 2021a). Second, firms sometimes can make minor amendments on the issue size that is initially announced. Eikon reports the updated date as the announcement day. However, it can be misleading to use the updated days instead of originals since the true effect mostly hidden around the initial days. Third, the announcements of delisted companies are also included. Hence, the dataset consists of 343 bonus issue announcements for the analysis period. Historical daily stock price data is extracted from the Worldscope database. Fxplus platform (local data provider) is also used to obtain missing price data, especially for delisted companies.

The main reason to use hand-collected data is to be able to reach the details. PDP provides information such as the source of the issue and the amount of capital increase. Two different main source types for bonus issues are detected. Firms may prefer to distribute bonus shares via last year's net income or use internal resources (i.e. equity accounts) such as retained earnings and capital reserves to increase the existing capital. Figure 1 describes the main and sub-group sources of bonus issues in Turkey.

Companies listed in BIST generally announce the board's decision regarding profit distribution of last year's net income (DIV) after their annual financial report become publicly available. Firms mostly specify the intended amount of capital increase and the type of dividend through these announcements. Firm boards can choose between keeping the last year's net income inside or distributing it by cash, shares or combinations of the two. Bonus issues from DIV are grouped into two to analyse whether the announcement's impact of bonus shares that are distributed alongside cash dividend (DIV_C) is different from pure bonus issue (DIV_NC). Panel C in Table 1 shows the number of announcements regarding these groups.

Figure 1.

Types of bonus issues in Turkey

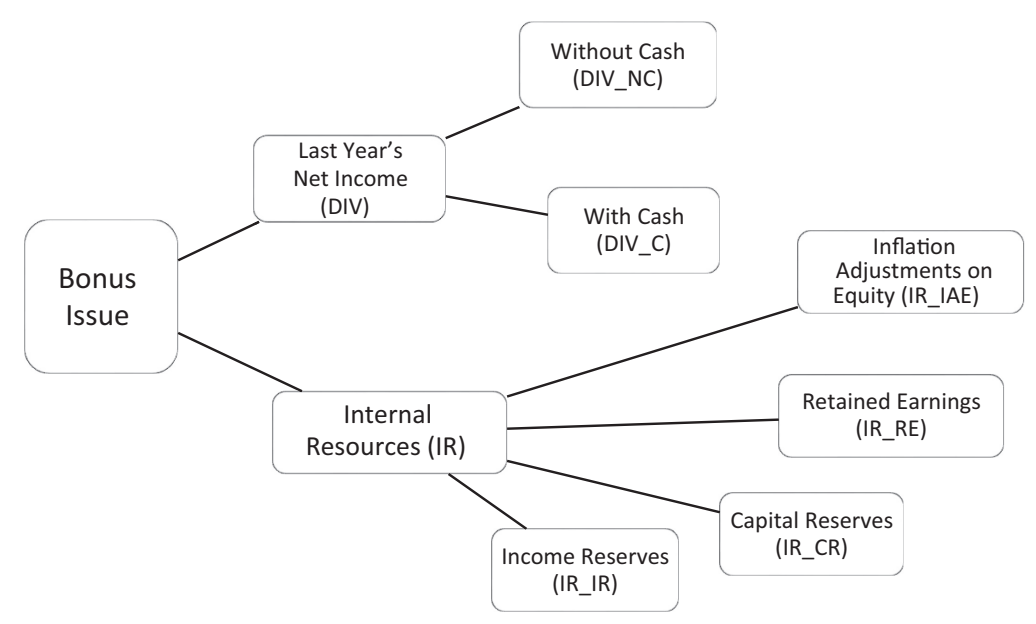


Panel A: Descriptive statistics for the amount of capital increase via bonus issue (in thousands TRY)

\begin{tabular}{|c|c|c|c|c|}
\hline Total & Mean & Std. Dev & Min & $\operatorname{Max}$ \\
\hline $28,558,443$ & 83,995 & 136,078 & 660 & $1,000,000$ \\
\hline \multicolumn{5}{|c|}{ Panel B: Timing of the bonus issue announcements } \\
\hline Year of the announcement & \# Of issues & \multicolumn{2}{|c|}{ Month of the announcement } & \# Of issues \\
\hline 2010 & 37 & \multicolumn{2}{|l|}{ January } & 8 \\
\hline 2011 & 35 & \multicolumn{2}{|l|}{ February } & 61 \\
\hline 2012 & 43 & \multicolumn{2}{|l|}{ March } & 98 \\
\hline 2013 & 45 & \multicolumn{2}{|l|}{ April } & 65 \\
\hline 2014 & 30 & \multicolumn{2}{|l|}{ May } & 39 \\
\hline 2015 & 28 & \multicolumn{2}{|l|}{ June } & 12 \\
\hline 2016 & 34 & \multicolumn{2}{|l|}{ July } & 13 \\
\hline 2017 & 29 & \multicolumn{2}{|l|}{ August } & 10 \\
\hline 2018 & 40 & \multicolumn{2}{|l|}{ September } & 7 \\
\hline \multirow[t]{2}{*}{2019} & 22 & \multicolumn{2}{|l|}{ October } & 12 \\
\hline & & \multirow{2}{*}{\multicolumn{2}{|c|}{$\begin{array}{l}\text { November } \\
\text { December }\end{array}$}} & 10 \\
\hline Average & 34 & & & 8 \\
\hline
\end{tabular}

Panel C: Number of bonus issue announcements according to sub-groups

\begin{tabular}{lclr} 
Last Year's income groups & \# Of issues & Internal resources groups & \# Of issues \\
\hline With cash (DIV_C) & 73 & Inflation adjustments on equity (IR_IAE) & 42 \\
Non-cash (DIV_NC) & 76 & Retained earnings (IR_RE) & 46 \\
& & Income reserves (IR_IR) & 52 \\
Total & \multirow{2}{*}{149} & Capital reserves (IR_CR) & 54 \\
& & Total & 194 \\
\hline
\end{tabular}

Panel D: Descriptive statistics for issue size groups

\begin{tabular}{|c|c|c|c|c|c|}
\hline Issue size groups & $N$ & Mean for issue size & Std. Dev & Min & Max \\
\hline Q1 & 84 & 0.0675 & 0.0244 & 0.0102 & 0.1062 \\
\hline Q2 & 84 & 0.1646 & 0.0361 & 0.1085 & 0.2464 \\
\hline Q3 & 89 & 0.4171 & 0.1275 & 0.25 & 0.741 \\
\hline Q4 & 87 & 4.0723 & 9.9067 & 0.75 & 79 \\
\hline
\end{tabular}

Panel E: Number of bonus issue announcements according to sectoral belonging

\begin{tabular}{lclc} 
Non-financial industries & \# Of issues & Financial industries & \# Of issues \\
\hline $\begin{array}{l}\text { Chemicals and fertilizers, pharmaceuticals and } \\
\text { plastics }\end{array}$ & 37 & Diversified REITs & 43 \\
Wholesale, retail and distributions & 21 & $\begin{array}{l}\text { Investment holding } \\
\text { companies }\end{array}$ & 31 \\
Iron and steel & 21 & Banks & 21 \\
Cement and concrete manufacturing & 16 & Factoring and leasing & 20 \\
Construction and engineering & 15 & Insurance & 13 \\
Auto, truck and motorcycle parts & 13 & Venture capital & 10 \\
Computer, software and hardware (IT) & 10 & Investment trust & 9 \\
Others & 54 & Brokerage services & 9 \\
Total & 187 & Total & 156
\end{tabular}

Cracking the fault line in stock markets 
JCMS 5,1

74

The second main source of bonus issue is internal resources (IR). Differently from DIV, firm boards can choose any time to announce a bonus issue through IR. The hand-collected data indicate that four different types of IR used in Turkey. The first one is inflation adjustments on equity (IR_IAE), with account number 502 in the Uniform Chart of Accounts (UCA) applied in Turkey. The inflation adjustment is applicable in countries with high inflation, and International Accounting Standards (IAS) Section 29 specifies the conditions when a revaluation of the financial reports should be applied. IAS defines a country as hyperinflationary if three years of aggregated inflation is calculated approximately $100 \%$ or more. Since Turkey was experiencing high inflation rates during the 1990s and in the early years of the new millennia, financial reports were prepared according to revaluation principles that are determined by realised inflation rates. Capital Market Board of Turkey (CMB) decides to suspend revaluation of the financial reports thanks to relatively lower inflation rates by 2005 .

Companies may prefer to use their retained earnings to distribute bonus shares. In total, 46 bonus issue announcements are detected in which retained earnings are used as the primary source. This account aggregates net income acquired throughout previous years. After subtracting the legal reserves from the annual net profit, the remaining non-distributed amount is added to this account. Account number for retained earnings is defined as 570 in UCA.

The third sub-group of IR is income reserves (IR_IR), listed as number 54 in UCA. According to the Turkish Commercial Code (TCC), $\%$ of the annual net profit must be kept under legal reserves. This action, also known as the first legal reserve, continues until it reaches $20 \%$ of the paid-in capital. Also, for the cases where cash distribution exceeds $5 \%$ of the paid-in capital, $10 \%$ of the distributed dividend must be kept as the second legal reserve. Other accounts that are considered under income reserves are special reserves, extraordinary reserves and special funds.

The last sub-group of IR is capital reserves (IR_CR), defined as number 52 in UCA. This account consists of sub-accounts named shares premium, revaluation accounts for investments and fixed assets, revaluation account from subsidiaries and other capital reserves. Changes caused by capital transactions are recorded in these accounts. For example, if newly issued shares are sold in excess of par value, the additional amount is recorded under the shares premium account. Also, when tangible fixed assets (machinery and equipment or buildings) of a company are subject to revaluation, it needs to be shown under capital reserves.

In general, there are six steps in a bonus issue. These are described in Figure 2 from the initial stage (board decision and the announcement day) until the completion (payment day) with a real example. The average number of days between bonus issue announcements and the ex-dates is 71 calendar days for the sample. When a firm decides to increase the existing capital via bonus issue, the board must announce the details via PDP. Second, the firm must apply to $\mathrm{CMB}$ and wait until the decision is approved. Approval of the application is published in the weekly bulletin of CMB. Then, investors, who own the shares of the capital

Figure 2.

The timeline of a bonus issue - the example of KARTN (2020)
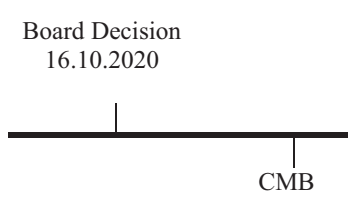

Application

30.10 .2020
Record date

25.12.2020
Approval

18.12.2020

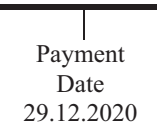


increasing firm on the closing of the ex-date, are entitled to receive bonus shares on a pro-rata basis on the record date. The settlement of bonus shares is done on the payment data.

Table 1 provides the details regarding the dataset. The hand-collected data suggest that the total amount of capital increase through bonus issue is calculated as 28.5 billion TRY for the analysis period. A total of 168 unique firms prefer a bonus issue at least once for the last decade. Panel A shows other statistics for bonus issues in Turkey. The paper also examines whether the timing of the bonus issue matters or not. As stated in panel $\mathrm{B}$, the most frequent months for bonus issue announcements are March, April, February and May, respectively. The majority of firms announce their latest annual financial reports by February and March. Also, general meetings are mostly held in April and May. It seems that company boards generally prefer to announce bonus issue decision around these important events.

Last but not least, bonus issues are divided into four groups according to the distribution rate by using quartile ranges. Panel $\mathrm{D}$ presents descriptive statistics for these groups. The average distribution ratio for the largest issue size group (Q4) is found as $407 \%$, while it is only $6.75 \%$ for the smallest group (Q1). Finally, the sectoral division is used to test its impact on market reaction. Eikon and Fxplus databases are used to obtain sectoral belonging information. Firms are grouped into two in regards to operating mainly in the finance sector or not.

\section{Methodology}

\subsection{Event study methodology}

Measuring the impact of a corporate event is a commonly applied technique in the finance literature to understand investor's behaviour. The event study is an appropriate method to analyse the market reaction for both pre- and post-event periods. The idea is simple, yet effective in event studies where actual returns are compared with the expected ones to decide whether an event-induced anomaly exists or not.

One of the research interests of this study is to examine investor's perception of the initial news of capital increase via bonus shares in BIST. Thus, the event is defined as the bonus issue announcement where the release day of the announcement is set as day zero, which represents the event day (i.e. $t_{e}=0$ ). Figure 3 illustrates the timeline of an event study. As previously mentioned, to conduct an event study, expected and realised returns must be compared. To do so, it is necessary to go back a certain period from the announcement, which is shown as the estimation period in the figure. This is applied to have enough observations for the expected return calculation for each security in the sample. It is suggested to go a trading year backwards for daily basis analysis, which is approximately 250 days before the event (MacKinlay, 1997; Kolari and Pynnonen, 2011).

The length of the estimation period is set as 240 days to calculate the expected return for each security. Notation $t_{a}$ represents the starting day while $t_{1}-1$ is the ending day of the estimation period. To minimise the effect of confounding events, which may reduce the power of the true event, the length of the main event window $\left(t_{1}, t_{2}\right)$ is determined as 21 days (10 days before and after the event), where $t_{1}$ and $t_{2}$ are starting and ending days of the analysis period. Thus, the broadest event window can be represented as $(-10,10)$. However, multiple event windows are used to observe both pre- and post-announcement periods. For instance, to examine possible insider trading activity, $(-5,-1)$ and $(-2,-1)$ event windows
Cracking the fault line in stock markets 
JCMS 5,1

are used. On the other hand, $(0,2),(0,5)$ and $(0,10)$ windows are applied to analyse the eventinduced reaction.

3.1.1 Expected and abnormal return calculation. Event-induced impact on the stock return is measured by comparing the realised and expected returns for the selected event windows. Expected returns are calculated by using the historical returns of shares in the estimation period. Researchers use various models for expected return calculation. The market model is preferred in this study, as shown in Eqn (1), since it takes both company-specific risk and benchmark index into account.

$$
A R_{i, t}=R_{i, t}-\widehat{\alpha}_{i}-\widehat{\beta}_{i} R_{m, t}
$$

$A R_{i, t}$ refers to abnormal return for stock $i$ at $t$, which equals to realised return $\left(R_{i, t}\right)$ of the same stock minus expected return that is calculated by the estimated model parameters. $R_{m, t}$ is the benchmark index return, $\widehat{\beta}_{i}$ is the stock-specific risk and $\widehat{\alpha}_{i}$ is the constant term.

Campbell et al. (1998) mention certain advantages to use market model compared to the market return model in which model parameters, $\alpha_{i}$ and $\beta_{i}$, are restricted to 0 and 1 , respectively. This means that the market return model assumes company-specific risk is constant for all stocks in the sample, and stock prices move the same as the benchmark index. Thus, biases may occur if restrictions are actually not correct. Also, the constant mean return model is not preferred since it only calculates simple average share returns during the estimation period and ignores the benchmark index.

After calculating single-day abnormal returns for each stock within specified event windows, as a second step, stock-specific cumulative abnormal returns (CAR) are aggregated, which is shown in Eqn (2).

$$
\widehat{\mathrm{CAR}}_{i,\left(t_{x}, t_{y}\right)}=\sum_{t_{x}}^{t_{y}} A R_{i, t}, t \in\left(t_{x}, t_{y}\right)
$$

$\left(t_{x}, t_{y}\right)$ represents a set of sub-event windows of the main event window $\left(t_{1}, t_{2}\right)$.

An example regarding applying Eqn (2) may provide a better understanding of the calculation steps. Suppose that the population consists of only two firms, so-called firm $a$ and firm $b$, which distribute bonus shares only once within ten years. Let $(0,1)$ be the sub-event window to analyse how the bonus issue announcements affect share prices within two days. Then, let $A R_{a, 0}$ and $A R_{b, 0}$ be given abnormal returns at day 0 , equal to 2 and $1 \%$, respectively. Also, let $A R_{a, 1}$ and $A R_{b, 1}$ be given values of abnormal returns at day 1, equal to 1 and $0.5 \%$, respectively. Then, Eqn (2) for each firm is calculated as follows:

$$
\mathrm{CAR}_{a,(0,1)}=0.02+0.01=0.03, \mathrm{CAR}_{b,(0,1)}=0.01+0.005=0.015
$$

The last step before the statistical testing process is to find cumulative average abnormal returns (CAAR), which allows us to infer the overall impact of bonus issue announcements for companies in BIST. As formulated in Eqn (3), CAAR for a given event window is calculated as the sum of CAR divided by the number of unique events $(N)$ in the sample.

$$
\widehat{\mathrm{CAAR}}_{\left(t_{x}, t_{y}\right)}=\frac{1}{N} \sum_{i=1}^{N} \widehat{\operatorname{CAR}}_{i,\left(t_{x}, t_{y}\right)}
$$

To find CAAR for the hypothetical event study, Eqn (3) is applied as follows:

$$
\mathrm{CAAR}_{(0,1)}=\frac{0.03+0.015}{2}=0.0225
$$


Since there are only two events in the population, the sum of CARs is divided into two. Thus, the two-day average cumulative market reaction for the example is $2.25 \%$.

3.1.2 Statistical testing. CAARs for each selected event window must be statistically tested to decide whether a market anomaly exists around bonus issue announcements. The null hypothesis is set as CAAR for the specified event window equals zero, which means that event-induced market anomaly does not exist.

$$
H_{0}: \operatorname{CAAR}_{\left(t_{x}, t_{y}\right)}=0, H_{1}: \operatorname{CAAR}_{\left(t_{x}, t_{y}\right)} \neq 0
$$

The study prefers to apply both parametric and non-parametric approaches to obtain more profound results. If both test results are found significant, then the market anomaly is reported as strong. When significance is only found by one of these tests, a weak anomaly is suggested. Finally, if both tests fail to report significant results, then the paper concludes that bonus issue announcements do not cause an anomaly in the market.

First, a cross-sectional $t$-test is applied for multiple-day calculations, specified in Eqs (4) and (5) as formulated in Frunza (2016).

$$
t_{\mathrm{crss}}=\frac{\widehat{\mathrm{CAAR}}}{\left(t_{x}, t_{y}\right)}
$$

$\widehat{\sigma}$ is the predicted SD of CAAR within a specific event window $\left(t_{x}, t_{y}\right)$ and calculated as follows:

$$
\widehat{\sigma}_{\mathrm{CAAR}_{\left(t_{x}, t_{y}\right)}}=\frac{1}{\sqrt{N}} \sqrt{\sum_{i=1}^{N}\left(\widehat{\mathrm{CAR}}_{i,\left(t_{x}, t_{y}\right)}-\widehat{\mathrm{CAAR}}_{\left(t_{x}, t_{y}\right)}\right)^{2}}
$$

Since the observation number is small for some cases, a non-parametric approach known as the generalised sign test is used, as formulated in Cowan (1992). Eqs (6)-(8) show the steps of this test.

$$
Z_{\text {sign }}=\frac{\phi-N \widehat{p}}{\lfloor N \widehat{p}(1-\widehat{p})\rfloor^{\frac{1}{2}}}
$$

$\phi$ refers to the number of events that has positive CAR within a specified event window. $N$ shows the total number of events for the sample.

$$
\widehat{p}=\frac{1}{N} \sum_{i=1}^{N} \frac{1}{t_{a}-\left(t_{1}-1\right)} \sum_{t_{a}}^{t_{1}-1} S_{i, t}
$$

$\widehat{p}$ is the estimated parameter of the binomial distribution, while $t_{a}-\left(t_{1}-1\right)$ is the number of days within the estimation period, which is set as 240 days in this study (i.e. $(-250,-11)$ ). $S_{i, t}$ shows the sign of abnormal return for the event $i$ at time $t$ while it is calculated as follows:

$$
S_{i, t}=\left\{\begin{array}{l}
1, \text { if } A R_{i, t}>0 \\
0 \text { otherwise }
\end{array}\right\}
$$

\subsection{Independent groups comparison}

Factors that likely impact the magnitude of the bonus issue announcements are analysed according to the research questions mentioned in the second section. Since pairwise and 
JCMS 5,1

multiple groups are used for comparison purposes, an independent two-sample $t$-test and oneway ANOVA are applied to understand what triggers stock returns around the event days. The test power of shorter event windows is higher since the probability of including confounding events is low (Kothari and Warner, 2007). Thus, the paper prefers to present the results under the $(0,2)$ event window for pairwise comparisons. The reason to use abnormal returns under $(0,2)$ is that the return anomaly mostly occurs after the announcement release. If the paper fails to show any significant difference for this window, it is less likely to find it for other windows.

Analyses of pairwise comparison are conducted by using last year's net income groups, sectoral belonging, market sentiment and timing of the announcement groups. Pairwise comparison is hypothesised as follows:

$$
H_{0}: \mu_{1}-\mu_{2}=0, \ldots H_{1}: \mu_{1}-\mu_{2} \neq 0
$$

First, before comparing the group means (i.e. CAARs), homogeneity of variances is tested using Levene's test. Student's $t$-test is employed for the groups in which equality of variance assumption holds. Nonetheless, Welch's $t$-test is used for those groups with unequal variances as suggested in Ruxton (2006), who also documents the advantages of this test over the non-parametric Mann-Whitney $U$ test to handle the Type I error problem.

On the other hand, one-way ANOVA is employed to compare issue size and internal resource groups since both have more than two sub-groups. Multiple comparisons are hypothesised as follows:

$$
\begin{gathered}
H_{0}: \mu_{1}=\mu_{2}=\mu_{3}=\mu_{4} \\
H_{1}: \text { At least mean of one group is different }
\end{gathered}
$$

Since homogeneity of variance assumption does not hold for both issue size and internal resources groups, Welch $F$-test is reported in ANOVA tables. For robustness check, the paper also reports the non-parametric Kruskal-Wallis test. After checking the means of equality among the groups, post hoc tests are applied to detect which group is different from others. For ANOVA, Games-Howell post hoc test is applied for multiple comparisons due to violation of homogeneity assumption of variances, while for Kruskal-Wallis, results for DunnBonferroni post hoc test is reported.

It is assumed that CARs, used in comparison tests, are independently distributed across the different groups since most of the event dates occur in different periods. Thus, it is not likely to observe any interaction among the observations. However, to prevent a possible violation of the independence assumption due to similar event dates, the announcements of firms from the same sector with close event days are excluded for robustness purpose. In total, 17 latter announcements are removed from the sample, which occurred within three days after the initial ones. However, excluding these events does not affect the significance level of test results, which implies that the independence assumption is not violated.

\section{Findings}

\subsection{Comparison of main source groups of bonus issue}

The first part of the analysis compares main source groups (i.e. DIV and IR) to understand investors' behaviour around bonus issue announcement. Figure 4 shows CAAR for both groups under $(-10,10)$ event window. Average abnormal returns (AAR) represent a singleday market anomaly, while CAAR values imply a multi-day effect after AARs are aggregated to find the overall market anomaly. Thus, CAAR values at a single time point show the effects of previous days, including the selected day. The same bounds are used for the vertical axis to compare the groups better. Findings suggest that firms that apply bonus issue through IR 


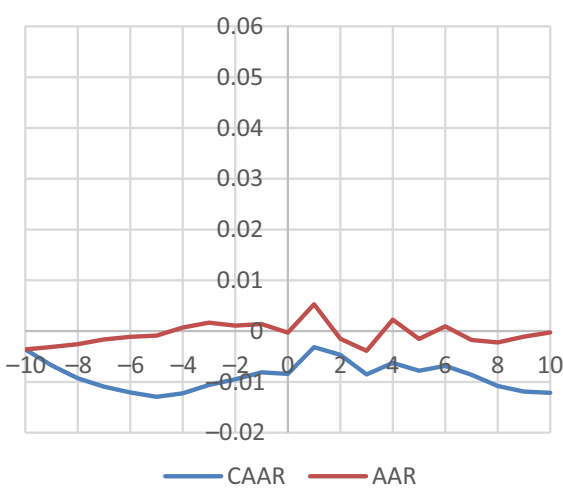

Panel A: Last year's net income group

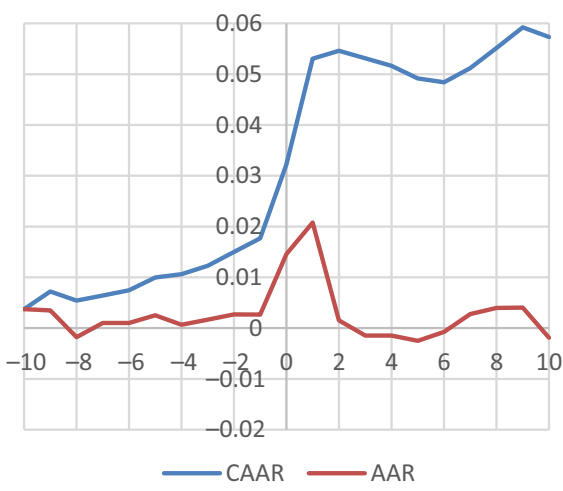

Panel B: Internal resource group
Cracking the fault line in stock markets

Figure 4. Market reaction to bonus issue announcements according to main source groups

show better performance around the announcement days in general. At the end of the event window, CAAR is calculated around $5.70 \%$ for the IR group. However, AAR suggests that the biggest portion of the anomaly occurs within two days. On the other hand, it seems investors are not impressed by the announcements when firms prefer DIV for bonus issues. Nevertheless, CAAR is measured around $-1 \%$ for 21 days period.

A possible explanation for this difference can be attributed to the tax advantage of receiving bonus shares instead of cash dividends. The implied tax rate for cash dividends is $15 \%$ in Turkey, while bonus share distribution, described as a form of dividend payment method, has tax exemption during the study period. Also, the information content of DIV represents the previous year's operational performance, unlike bonus issues from IR, which may convey information of many years.

Abnormal returns are statistically tested for both groups under six different event windows to conclude whether a market anomaly exists or not. Table 2 shows event study finding for these groups. Event windows $(-5,5)$ and $(-2,2)$ cover periods before and after the bonus issue announcement to show the total effect. However, $(0,5)$ and $(0,2)$ concentrate on post-announcement period, while $(-5,-1)$ and $(-2,-1)$ analyse pre-announcement periods.

Findings suggest that CAAR for the IR group is statistically significant under cross sectional and sign tests for all examination periods. Three-day CAAR after the announcement is found $3.68 \%$, while almost in two-third of the events, a positive reaction is recorded.

\begin{tabular}{|c|c|c|c|c|c|c|}
\hline Event windows & Groups & CAAR $(\%)$ & Pos/Neg & Cross-sec & Sign $t$ & \\
\hline \multirow{2}{*}{$(-5,5)$} & DIV & 0.43 & $71 / 78$ & 0.828 & 0.031 & \\
\hline & $\mathrm{IR}$ & 4.17 & $115 / 79$ & $3.179^{* * * *}$ & $3.038^{* * * *}$ & \\
\hline \multirow{2}{*}{$(-2,2)$} & DIV & 0.59 & $73 / 76$ & 1.469 & 0.359 & \\
\hline & $\mathrm{IR}$ & 4.23 & $121 / 73$ & $4.629^{* * * *}$ & $3.900^{* * *}$ & \\
\hline \multirow[t]{2}{*}{$(0,5)$} & DIV & 0.03 & $69 / 80$ & 0.079 & -0.297 & \\
\hline & IR & 3.15 & $110 / 84$ & $2.801^{* * * *}$ & $2.320^{* * *}$ & \\
\hline \multirow[t]{2}{*}{$(0,2)$} & DIV & 0.35 & $67 / 82$ & 0.347 & -0.625 & \\
\hline & $\mathrm{IR}$ & 3.68 & $120 / 74$ & $4.435^{* * * *}$ & $3.756^{* * *}$ & \\
\hline \multirow[t]{2}{*}{$(-5,-1)$} & DIV & 0.39 & $75 / 74$ & 1.063 & 0.687 & Table 2. \\
\hline & $\mathrm{IR}$ & 1.02 & $106 / 88$ & $2.239^{* * *}$ & $1.745^{*}$ & Event study results for \\
\hline \multirow[t]{2}{*}{$(-2,-1)$} & DIV & 0.25 & $75 / 74$ & 1.103 & 0.687 & the main source of \\
\hline & $\mathrm{IR}$ & 0.54 & $113 / 81$ & $2.014^{* * *}$ & $2.751^{* * * *}$ & bonus issues \\
\hline
\end{tabular}


JCMS 5,1

80

There is also a sign for information leakage since under five and two-day event windows, CAARs are found positive and significant (1.02 and $0.54 \%$, respectively). On the other hand, CAAR for none of the cases is found significant for the DIV group. This implies that investors are not impressed when firms announce to distribute last year's net income as bonus shares. Although CAAR for $(0,2)$ window is measured $0.35 \%, 82$ cases out of 149 are found as negative.

Finally, the difference of CAAR for these groups is tested under $(0,2)$. Welch's $t$-test results are presented in panel A of Table 3. CAAR difference between DIV and IR is found significant. Thus, the paper shows empirical evidence that investors in BIST react differently (more positively) for bonus issues when internal resources are used compared to last year's net income. This study is the first attempt to analyse and document the performance distinction of DIV and IR groups. Also, the variation of abnormal returns for the IR group is much higher than the DIV group since return variances are not homogeneous. This means that announcements' impact on stock returns for IR is not as monotonous as for DIV.

Another novel aspect of the paper is investigating the division of main source groups. Both main source groups are divided into sub-groups. Section 4.1.1 investigates DIV subgroups, which are bonus shares from last year's income simultaneously with cash dividend (DIV_C) and without cash dividend (DIV_NC), respectively. Findings regarding IR subgroups are presented in section 4.1.2.

4.1.1 Last year's income sub-groups. The hand-collected dataset suggests that 76 and 73 announcements are made during the study period for DIV_C and DIV_NC groups, respectively. This section discusses event study findings and $t$-test results to compare the mean difference of these groups.

First, sub-groups of DIV are compared visually, which is given in Figure 5. CAARs are found around $-1 \%$ under the main event window for both groups. Also, AARs show limited return variation for the daily basis analysis.

Second, event study findings are represented in Table 4 for the announcements belong to these groups under six different event windows. CAARs are found insignificant for all cases except the pre-announcement window $(-2,-1)$ for DIV_C. Both test results are significant at the $10 \%$ level, meaning that the return anomaly exists for the pre-event period for two-day. CAAR under $(-5,-1)$ is found around $1 \%$ and significant only for cross-sectional $t$-test. The study concludes that the presence of anomaly is weak for this event window since the sign test result does not support it. On the other hand, after the release of the news, it seems investors are not impressed with the bonus issue from last year's net income regardless of being distributed with or absence of cash.

The paper tests whether the average market reaction differs for DIV_C and DIV_NC groups. Student's $t$-test results are presented in panel B of Table 3, which suggest that market anomaly does not vary among these groups under $(0,2)$ event window. Findings indicate that variations of abnormal returns for both groups are similar by addressing homogeneity. The paper's findings show similarities with David and Glinger (2016), who compare and cannot find any difference between the market reaction of cash dividends and optional bonus distribution announcements in France.

4.1.2 Internal resources sub-groups. In this section, IR is divided into four sub-groups according to the content obtained from bonus issue announcements provided by PDP. As mentioned in the second section, firms can use equity accounts to increase their existing capital. Panel C of Table 1 gives the number of announcements for IR sub-groups. Figure 6 exhibits abnormal returns around the announcement days of bonus issue through different internal resource categories. For all cases, CAAR until the end of the analysis period is found positive. Single-day abnormal return variations are visible within three days after the announcement for all groups except IR_CR. It seems that post-event anomaly among groups 


\begin{tabular}{|c|c|c|c|}
\hline $\begin{array}{l}\text { Panel A: CAR }(0,2) \text { difference for the main resource of bonus } \\
\text { issue groups }\end{array}$ & $\begin{array}{l}\text { Last year's } \\
\text { income }\end{array}$ & $\begin{array}{l}\text { Internal } \\
\text { resources }\end{array}$ & Mean difference \\
\hline $\begin{array}{l}\text { Mean } \\
\text { Standard deviation } \\
N \\
\text { Mean difference } \\
\text { Standard error difference }\end{array}$ & $\begin{array}{c}0.0034 \\
0.0445 \\
149\end{array}$ & $\begin{array}{c}0.0368 \\
0.1156 \\
194\end{array}$ & $\begin{array}{c}-0.0334^{* * * *} \\
0.0091\end{array}$ \\
\hline Panel B: CAR $(0,2)$ difference for last year's income groups & Non-cash & With cash & Mean difference \\
\hline $\begin{array}{l}\text { Mean } \\
\text { Standard deviation } \\
N \\
\text { Mean difference } \\
\text { Standard error difference }\end{array}$ & $\begin{array}{c}0.0067 \\
0.0424 \\
76\end{array}$ & $\begin{array}{c}0.0001 \\
0.0467 \\
73\end{array}$ & $\begin{array}{l}0.0066 \\
0.0073\end{array}$ \\
\hline Panel C: CAR $(0,2)$ difference for sectoral groups & Non-financial & Financial & Mean difference \\
\hline $\begin{array}{l}\text { Mean } \\
\text { Standard deviation } \\
N \\
\text { Mean difference } \\
\text { Standard error difference }\end{array}$ & $\begin{array}{c}0.0265 \\
0.1108 \\
187\end{array}$ & $\begin{array}{c}0.0174 \\
0.0659 \\
156\end{array}$ & $\begin{array}{l}0.0092 \\
0.0097\end{array}$ \\
\hline Panel D: CAR $(0,2)$ difference for market sentiment groups & Bullish & Bearish & Mean difference \\
\hline $\begin{array}{l}\text { Mean } \\
\text { Standard deviation } \\
N \\
\text { Mean difference } \\
\text { Standard error difference }\end{array}$ & $\begin{array}{c}0.0213 \\
0.0948 \\
181\end{array}$ & $\begin{array}{c}0.0236 \\
0.0918 \\
162\end{array}$ & $\begin{array}{r}-0.0023 \\
0.0099\end{array}$ \\
\hline Panel E: CAR $(0,2)$ difference for surprise and expected groups & Surprise & Expected & Mean difference \\
\hline $\begin{array}{l}\text { Mean } \\
\text { Standard deviation } \\
N \\
\text { Mean difference } \\
\text { Standard error difference }\end{array}$ & $\begin{array}{c}0.0377 \\
0.1194 \\
80\end{array}$ & $\begin{array}{c}0.0176 \\
0.0833 \\
263\end{array}$ & $\begin{array}{l}0.0201 \\
0.0143\end{array}$ \\
\hline Panel F: CAR $(0,2)$ difference for sequence groups & Initial & Latter & Mean difference \\
\hline $\begin{array}{l}\text { Mean } \\
\text { Standard deviation } \\
N \\
\text { Mean difference } \\
\text { Standard error difference }\end{array}$ & $\begin{array}{c}0.0450 \\
0.1225 \\
167\end{array}$ & $\begin{array}{c}0.0008 \\
0.0429 \\
176\end{array}$ & $\begin{array}{l}0.0442^{* * * *} \\
0.0097\end{array}$ \\
\hline
\end{tabular}




\section{JCMS \\ 5,1}

\section{2}

Figure 5.

Market reaction of last year's net income sub-groups

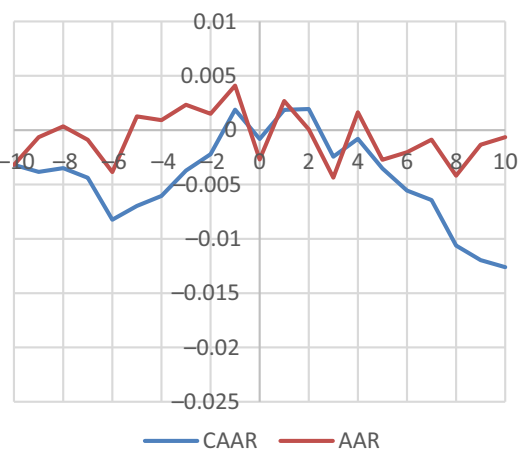

Panel A: Simultaneously with a cash dividend

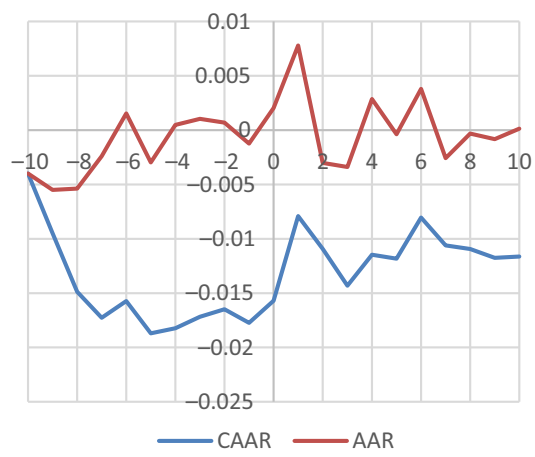

Panel B: Pure bonus issue from last year's net income

\begin{tabular}{llcccr}
\hline Event windows & Groups & CAAR $(\%)$ & Pos/Neg & Cross-sec & Sign $t$ \\
\hline$(-5,5)$ & DIV_C & 0.47 & $33 / 40$ & 0.733 & -0.589 \\
& DIV_NC & 0.39 & $38 / 38$ & 0.476 & 0.622 \\
$(-2,2)$ & DIV_C & 0.57 & $35 / 38$ & 0.996 & -0.121 \\
& DIV_NC & 0.63 & $38 / 38$ & 1.074 & 0.622 \\
$(0,5)$ & DIV_C & -0.54 & $29 / 44$ & -1.099 & -1.526 \\
& DIV_NC & 0.59 & $40 / 36$ & 1.047 & 1.082 \\
$(0,2)$ & DIV_C & 0.01 & $29 / 44$ & 0.010 & -1.526 \\
& DIV_NC & 0.68 & $38 / 38$ & 1.373 & 0.622 \\
$(-5,-1)$ & DIV_C & 1.01 & $39 / 34$ & $2.216^{* * *}$ & 0.816 \\
& DIV_NC & -0.20 & $36 / 40$ & -0.347 & 0.162 \\
$(-2,-1)$ & DIV_C & 0.56 & $43 / 30$ & $1.725^{*}$ & $1.752^{*}$ \\
& DIV_NC & -0.05 & $32 / 44$ & -0.178 & -0.758 \\
\hline
\end{tabular}

Table 4.

Event study results for last year's net income sub-groups vary while CAAR for IR_IAE is distinguished from others, which is found more than $10 \%$. However, for IR_RE and IR_IR groups, it is around 4\%. Unlike others, a negative market reaction is detected for the IR_CR for the post-event period.

Table 5 shows the event study findings of IR sub-groups. First, $(0,2)$ event window results are significant for all except IR_CR. The significance of the results is obtained only for IR_IAR and IR_IR groups under $(0,5)$ event window. CAAR for IR_RE is still positive but insignificant. Second, information leakage is detected only for IR_CR. 5 days event window for the pre-event period is significant under both test, while for the $(-2,-1)$ window, only the cross-sectional $t$-test confirms the leakage. Positive CAAR turns to negative for the postannouncement period.

One-way ANOVA analysis is conducted to test whether there exists any difference among IR sub-groups. CAAR results for $(0,2)$ are used to investigate this hypothesis. Figure 7 shows box plots of each group's distribution. Extreme outliers are trimmed for all groups. Also, normality test results assert distributions are not normal.

Despite the non-normality nature, one-way ANOVA test is performed since there is an adequate number of observations for all sub-groups, Welch $F$-test is reported since the homogeneity of variances assumption does not hold. Results for non-parametric KruskalWallis test is also provided for robustness purpose. Findings are presented in Table 6. First, the results of both tests confirm that at least one group's mean is different from others. However, significance under the Kruskal-Wallis test is detected at a 10\% level. Second, the 


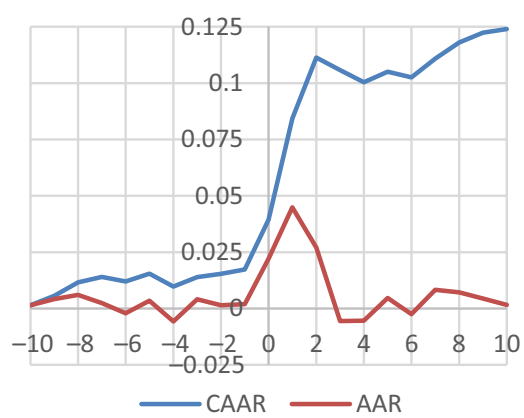

Panel A: Inflation adjustments on equity (IR_IAE)

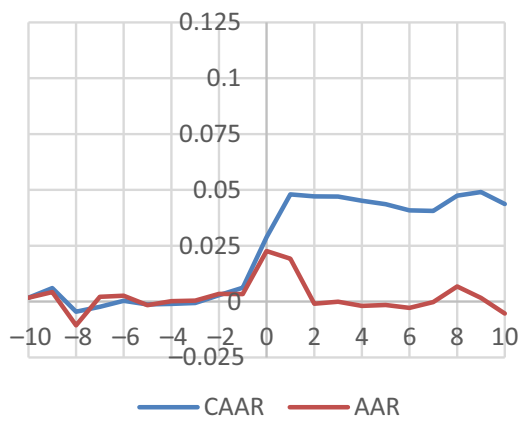

Panel C: Income reserves (IR_IR)

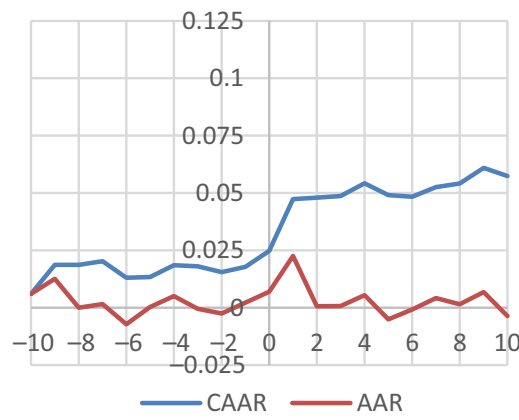

Panel B: Retained earnings (IR_RE)

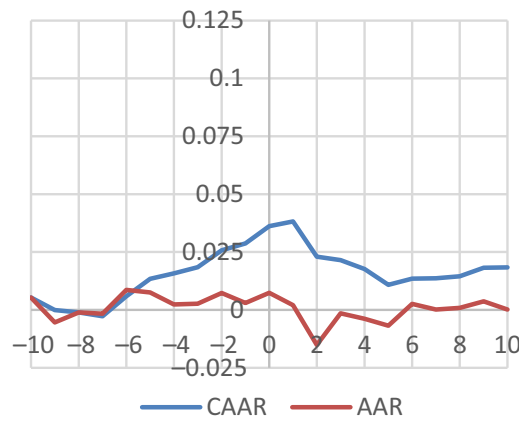

Panel D: Capital reserves (IR_CR)
Cracking the fault line in stock markets

83

post hoc test for multiple comparison purposes among groups is employed to understand which group is different. For one-way ANOVA, Games-Howell post hoc test is applied for multiple comparisons due to violation of the homogeneity assumption of variances. For Kruskal-Wallis, results for Dunn-Bonferroni post hoc test is reported in panel B.

Post hoc results for one-way ANOVA indicate that CAAR for IAE is different from RE and $\mathrm{CR}$ but not from IR. It means that when firms use inflation adjustment differences as a source of a bonus issue, the reaction is more severe than others except for income reserve source. Pairwise comparison under the Kruskal-Wallis only supports the existence of difference among IAE and CR groups. These findings are not in line with Adaoglu and Lasfer (2011). Although the authors underline the benefits of inflation adjustments on equity by addressing the tax aspect, the paper concludes that receiving bonus shares from different sources does not matter for investors in BIST.

\subsection{Issue size comparison}

This section aims to investigate whether the size of the bonus distribution is important or not. Data are divided into four groups by using quartile ranges. Panel D of Table 1 provides descriptive statistics for issue size groups. Q4 stands for the largest issues, while Q1 consist of bonus issues with the smallest size.

The motivation behind investigating issue size is related to the signalling hypothesis. Issue size shows the level of information content that a bonus issue announcement carries. Event study results that are provided in Table 7 suggest that there exist a positive association between issue size and abnormal return. Strong performance is observed for 
$\underset{5,1}{\mathrm{JCMS}}$

84

\begin{tabular}{|c|c|c|c|c|c|}
\hline Event windows & Groups & CAAR & Pos/Neg & Cross-sec & $\operatorname{Sign} t$ \\
\hline \multirow[t]{4}{*}{$(-5,5)$} & IAE & 9.30 & $25 / 17$ & $2.379^{* *}$ & 1.339 \\
\hline & $\mathrm{RE}$ & 3.61 & $23 / 23$ & 1.263 & 0.454 \\
\hline & IR & 4.33 & $33 / 19$ & $2.384^{* *}$ & $2.304^{* *}$ \\
\hline & $\mathrm{CR}$ & 0.50 & $34 / 20$ & 0.259 & $1.898^{*}$ \\
\hline \multirow[t]{4}{*}{$(-2,2)$} & $\mathrm{IAE}$ & 9.74 & $30 / 12$ & $3.681^{* * * *}$ & $2.882^{* * *}$ \\
\hline & $\mathrm{RE}$ & 2.99 & $29 / 17$ & $1.986^{* * *}$ & $2.228^{* * *}$ \\
\hline & IR & 4.77 & $33 / 19$ & $3.007^{* * * *}$ & $2.304^{* *}$ \\
\hline & $\mathrm{CR}$ & 0.46 & $29 / 25$ & 0.328 & 0.538 \\
\hline \multirow[t]{4}{*}{$(0,5)$} & $\mathrm{IAE}$ & 8.77 & $28 / 14$ & $2.708^{\text {***** }}$ & $2.265^{* *}$ \\
\hline & $\mathrm{RE}$ & 3.13 & $23 / 23$ & 1.244 & 0.454 \\
\hline & $\mathrm{IR}$ & 3.74 & $31 / 21$ & $2.707^{* * * *}$ & $1.748^{*}$ \\
\hline & $\mathrm{CR}$ & -1.79 & $28 / 26$ & -1.045 & 0.265 \\
\hline \multirow[t]{4}{*}{$(0,2)$} & IAE & 9.40 & $29 / 13$ & $3.807^{* * * *}$ & $2.573^{* *}$ \\
\hline & $\mathrm{RE}$ & 3.02 & $28 / 18$ & $2.299^{* * *}$ & $1.932^{*}$ \\
\hline & IR & 4.09 & $34 / 18$ & $3.167^{* * * *}$ & $2.581^{* * *}$ \\
\hline & $\mathrm{CR}$ & -0.57 & $29 / 25$ & -0.433 & 0.538 \\
\hline \multirow[t]{4}{*}{$(-5,-1)$} & $\mathrm{IAE}$ & 0.53 & $21 / 21$ & 0.409 & 0.104 \\
\hline & RE & 0.47 & $24 / 22$ & 0.442 & 0.750 \\
\hline & IR & 0.59 & $24 / 28$ & 0.866 & -0.196 \\
\hline & $\mathrm{CR}$ & 2.29 & $37 / 17$ & $3.478^{* * * *}$ & $2.715^{* * *}$ \\
\hline \multirow{4}{*}{$(-2,-1)$} & $\mathrm{IAE}$ & 0.34 & $26 / 16$ & 0.481 & $1.647^{*}$ \\
\hline & $\mathrm{RE}$ & -0.03 & $27 / 19$ & -0.054 & 1.637 \\
\hline & IR & 0.68 & $27 / 25$ & 1.269 & 0.638 \\
\hline & CR & 1.03 & $33 / 21$ & $2.466^{* *}$ & 1.626 \\
\hline
\end{tabular}

Figure 7.

Box plots of cumulative abnormal returns for each internal resource sub-group

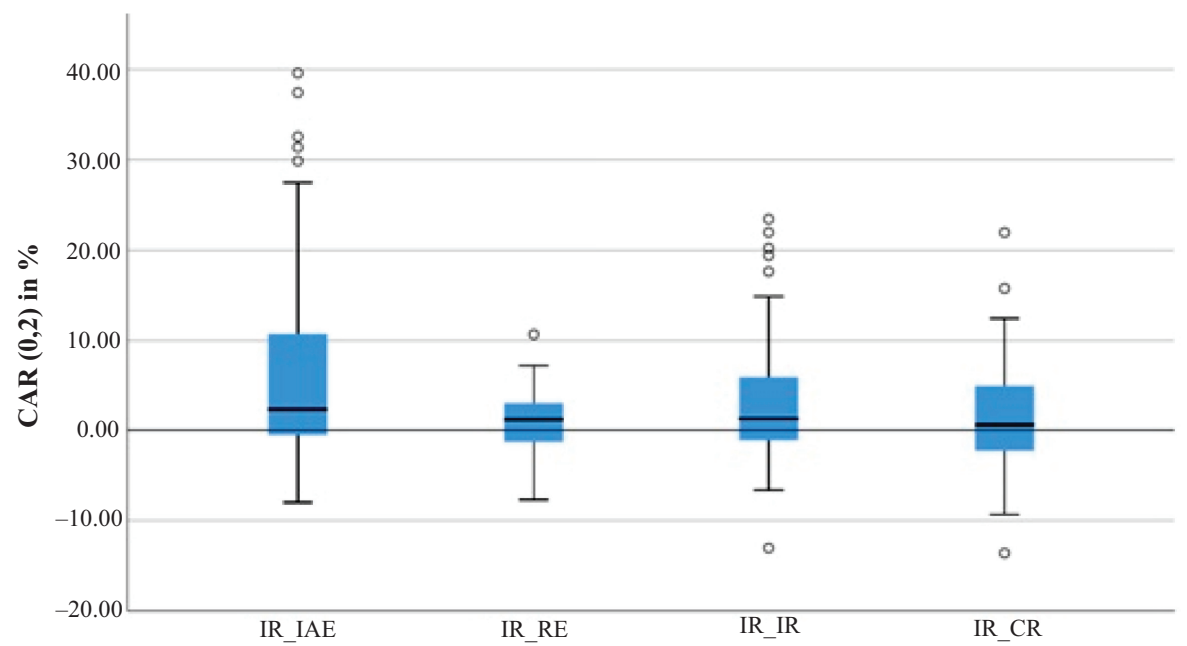

Internal Resource Groups

those companies that raise their capital at the highest rates. Findings are in line with the literature (Balachandran and Tanner, 2001; Barnes and Ma, 2002; Kato and Tsay, 2002; Pathirawasam, 2009). CAARs in all event windows are found positive and significant for Q4. Post-announcement cumulative abnormal return is detected over $7 \%$ on average. This shows 
Panel A: One-way ANOVA and Kruskal-Wallis test results

\begin{tabular}{lccc} 
& Statistic & df1 & df2 \\
\hline Welch $F$-test & $3.971^{* *}$ & 3 & \multirow{2}{*}{92.454} \\
Kruskal-Wallis H & $7.560^{*}$ & 3 & \\
\hline
\end{tabular}

Panel B: Post hoc tests for pairwise comparison

\begin{tabular}{lcccc} 
& \multicolumn{2}{c}{ One-way ANOVA } & \multicolumn{2}{c}{ Kruskal-Wallis } \\
Group comparison & Mean difference & Standard error & Test stat & Standard error \\
\hline IAE-RE & $0.0638^{* *}$ & 0.0213 & 19.860 & 11.983 \\
IAE-IR & 0.0393 & 0.0232 & 14.008 & 11.648 \\
IAE-CR & $0.0600^{* *}$ & 0.0222 & $31.180^{*}$ & 11.552 \\
RE-IR & -0.0244 & 0.0119 & -5.852 & 11.365 \\
RE-CR & -0.0038 & 0.0099 & 11.320 & 11.266 \\
IR-CR & 0.0206 & 0.0135 & 17.172 & 10.909 \\
\hline
\end{tabular}

Cracking the fault line in stock markets

Table 6.

Multiple comparisons of internal resources sub-groups

\begin{tabular}{|c|c|c|c|c|c|c|}
\hline Event window & Groups & CAAR $(\%)$ & Pos/Neg & Cross-sec & Sign $t$ & \\
\hline \multirow[t]{4}{*}{$(-5,5)$} & Q1 & 0.61 & $42 / 42$ & 1.217 & 0.489 & \\
\hline & Q2 & -0.30 & $36 / 48$ & -0.355 & -0.781 & \\
\hline & Q3 & 0.29 & $47 / 42$ & 0.217 & 0.943 & \\
\hline & Q4 & 9.56 & $61 / 26$ & $3.835^{* * *}$ & $3.804^{* * * *}$ & \\
\hline \multirow[t]{4}{*}{$(-2,2)$} & Q1 & -0.16 & $37 / 47$ & -0.432 & -0.604 & \\
\hline & $\mathrm{Q} 2$ & -0.09 & $38 / 46$ & -0.173 & -0.343 & \\
\hline & Q3 & 1.99 & $60 / 29$ & $1.961^{* *}$ & $3.701^{* * * *}$ & \\
\hline & Q4 & 8.60 & $60 / 27$ & $5.188^{* * *}$ & $3.59^{* * * *}$ & \\
\hline \multirow[t]{4}{*}{$(0,5)$} & Q1 & -0.35 & $33 / 51$ & -0.913 & -1.478 & \\
\hline & $\mathrm{Q} 2$ & -0.22 & $39 / 45$ & -0.384 & -0.125 & \\
\hline & Q3 & -0.01 & $49 / 40$ & -0.009 & 1.367 & \\
\hline & Q4 & 7.61 & $58 / 29$ & $3.585^{* * * *}$ & $3.161^{* * * *}$ & \\
\hline \multirow[t]{4}{*}{$(0,2)$} & Q1 & -0.64 & $27 / 57$ & $-1.977^{* *}$ & $-2.79^{* * *}$ & \\
\hline & $\mathrm{Q} 2$ & 0.19 & $41 / 43$ & 0.382 & 0.312 & \\
\hline & Q3 & 1.43 & $59 / 30$ & 1.515 & $3.489^{* * * *}$ & \\
\hline & Q4 & 7.74 & $60 / 27$ & $5.165^{* * *}$ & $3.590^{* * * *}$ & \\
\hline \multirow[t]{4}{*}{$(-5,-1)$} & Q1 & 0.97 & $48 / 36$ & $2.550^{* *}$ & $1.800^{*}$ & \\
\hline & $\mathrm{Q} 2$ & -0.08 & $35 / 49$ & -0.162 & -0.999 & \\
\hline & Q3 & 0.30 & $47 / 42$ & 0.573 & 0.943 & \\
\hline & Q4 & 1.95 & $51 / 36$ & $2.127^{* *}$ & $1.66^{*}$ & \\
\hline \multirow[t]{4}{*}{$(-2,-1)$} & Q1 & 0.48 & $42 / 42$ & $1.760^{*}$ & 0.489 & \\
\hline & $\mathrm{Q} 2$ & -0.28 & $41 / 43$ & -1.062 & 0.312 & Table 7. \\
\hline & Q3 & 0.56 & $52 / 37$ & 1.583 & $2.004^{* * *}$ & Event study results for \\
\hline & Q4 & 0.86 & $54 / 33$ & $1.769^{*}$ & $2.303^{* *}$ & issue size groups \\
\hline
\end{tabular}

that when the bonus issue size is announced over $75 \%$, investors react positively (see Figure 8).

On the other hand, results provide evidence that information leakage occurs before the announcement when the distribution rate is high. Both statistical test results suggest that CAAR for event windows $(-5,-1)$ and $(-2,-1)$ are positive and significant. Interestingly, pre-announcement CAAR for Q1 under $(-5,-1)$ is also found significant. It is assumed that despite insiders are aware of the forthcoming bonus issue announcement, the size of the issue 


\section{JCMS \\ 5,1}

\section{6}

Figure 8.

Market reaction of issue size groups

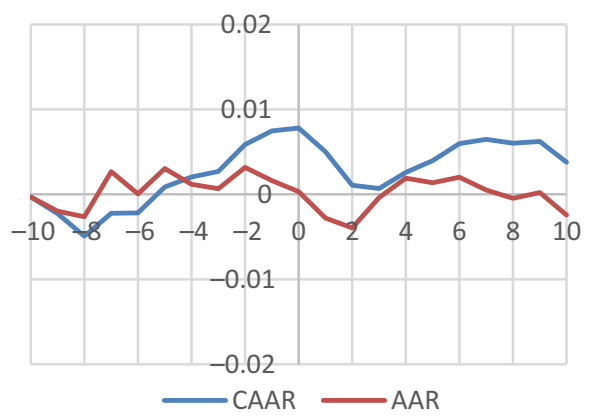

Panel A: Q1

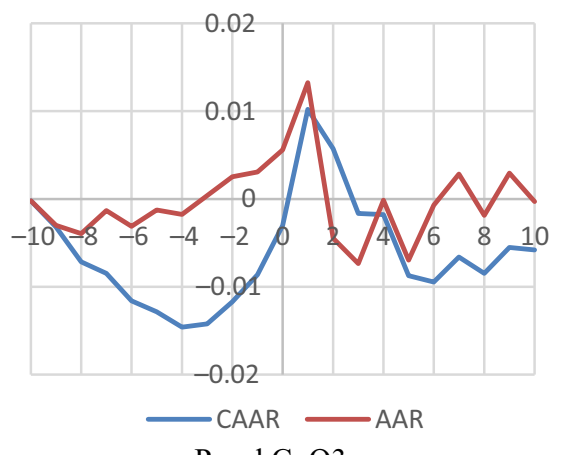

Panel C: Q3

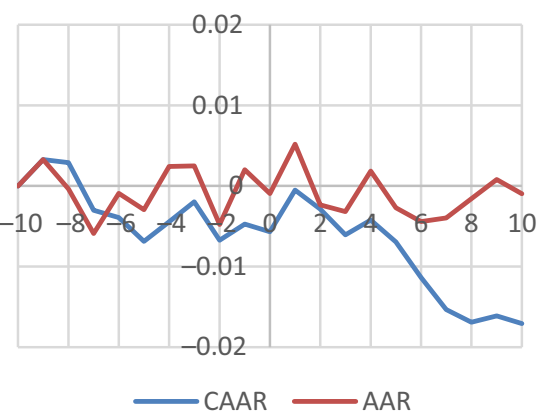

Panel B: Q2

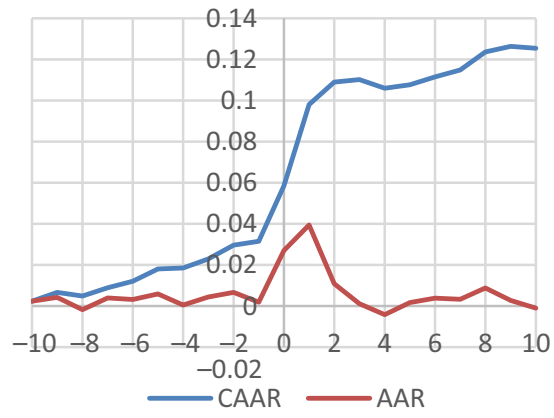

Panel D: Q4

might be ambiguous. For this reason, post-announcement CAAR becomes negative since investors' expectation regarding the issue size is not fulfilled.

On the other hand, a clear market anomaly is not observed for Q2 and Q3. Although CAAR under pre- and post-announcement windows for Q3 is found insignificant, the total effect for the five-day event window (i.e. $(-2,2)$ ) is detected as significant. Finally, Q2 results are insignificant for all cases, which means that investors are not impressed when the issue size is less than $25 \%$. However, their perception is not as negative as in the Q1 case under the $(0,2)$ event window. As a result, the size of a bonus issue seems extremely important for investors in BIST. On the other hand, the pre-announcement period results show that information leakage is more likely to occur when the bonus distribution rate is large.

A one-way ANOVA is conducted to check whether issue size groups react differently after the release of the announcement. Figure 9 depicts the distribution of the issue size groups. Extreme outliers are again extracted from the samples. Test of normality fails to reject the null hypothesis, which means that samples are not normally distributed. Since homogeneity of variance assumption is violated here, Welch $F$-test is reported in Table 8 . For robustness, Kruskal-Wallis test results are reported in the same table. The null hypothesis is rejected for both tests at the $1 \%$ significance level. Thus, findings provide evidence to show that CAAR for at least one issue size group differs from others.

Post hoc multiple comparison tests are applied to analyse further which issue size group differs. Results of post hoc tests for one-way ANOVA and Kruskal-Wallis are reported in panel B. Games-Howell treatment is applied due to unequal variances among the groups. Results suggest that CAAR for Q4 is different from other groups, and it holds for the post hoc 


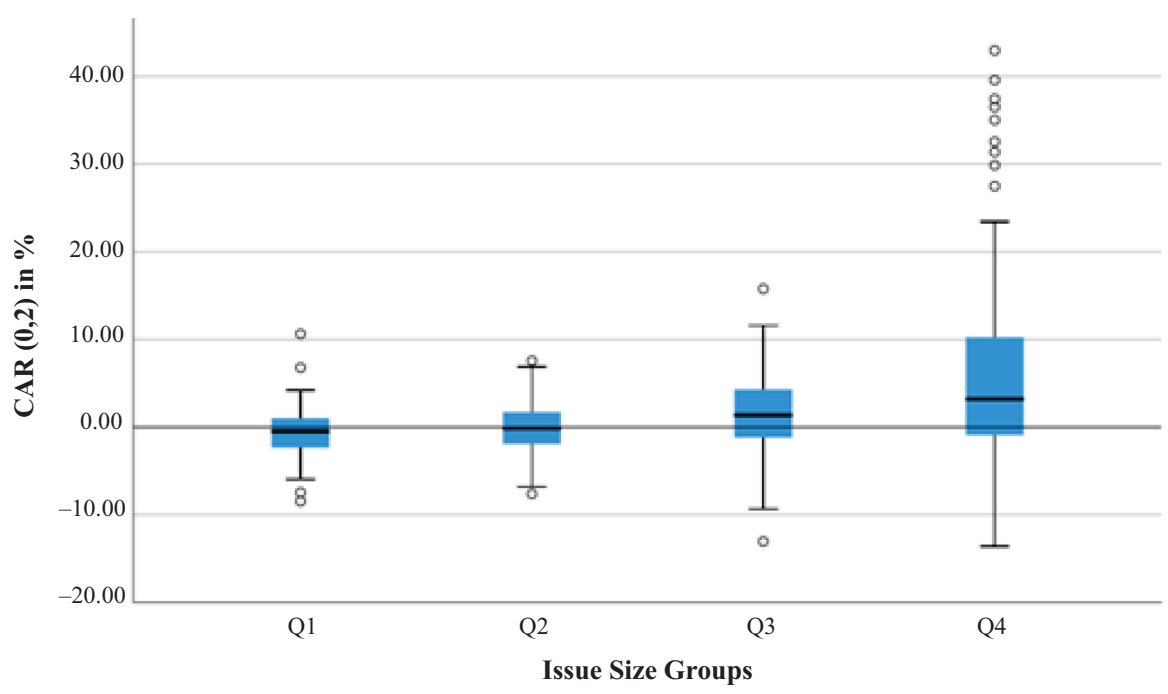

Panel A: One-way ANOVA and Kruskal-Wallis test results Statistic

\begin{tabular}{llll}
\hline Welch & $13.104^{* * *}$ & 3 & 175.621 \\
Kruskal-Wallis H & $34.823^{* * *}$ & 3 & \\
\hline
\end{tabular}

Panel B: Post hoc tests for pairwise comparison

\begin{tabular}{lcccc} 
Group comparison & Mean difference & Standard error & Test stat & \multicolumn{2}{c}{ Kruskal-Wallis } \\
\hline Q1 - Q2 & $-0.0037^{* * *}$ & 0.0048 & -19.214 & 15.345 \\
Q1 - Q3 & $-0.0221^{* * * *}$ & 0.0058 & $-55.497^{* * *}$ & 15.128 \\
Q1 - Q4 & $-0.0730^{* * *}$ & 0.0136 & $-81.848^{* * *}$ & 15.212 \\
Q2-Q3 & $-0.0183^{* * *}$ & 0.0061 & $-36.283^{*}$ & 15.128 \\
Q2-Q4 & $-0.0693^{* * *}$ & 0.0137 & $-62.633^{* * *}$ & 15.212 \\
Q3-Q4 & $-0.0509^{* * *}$ & 0.0141 & -26.351 & 14.993
\end{tabular}

Cracking the fault line in stock markets

Figure 9.

Box plots of cumulative abnormal returns for each issue size group

test for Kruskal-Wallis except for the Q3-Q4 comparison. Moreover, Q3 seems dominant over Q1 and Q2 since the results of both post hoc tests are significant. On the other hand, no difference between Q1 and Q2 is detected in terms of market anomaly after the bonus issue announcement. Hence, event study findings are supported by multiple comparison tests, which implies that the larger the bonus issue size is, the higher abnormal returns occur.

Baker and Phillips (1993) mention about the positive psychological impact of bonus issues. Post-split performance of bonus issuing companies is checked to understand whether this statement holds in Turkey. The hypothesis is that if larger-sized issues provide more favourable signals than smaller ones, then the positive impact should be valid after the ex-date. Figure 10 compares issue size groups according to their post-split performance.

The post-split market reaction for issue size groups provides interesting insights. For this case, day 0 refers to the split day. Compared to announcement days, market participants' 
JCMS

5,1

88

Figure 10.

Post-split performance of issue size groups

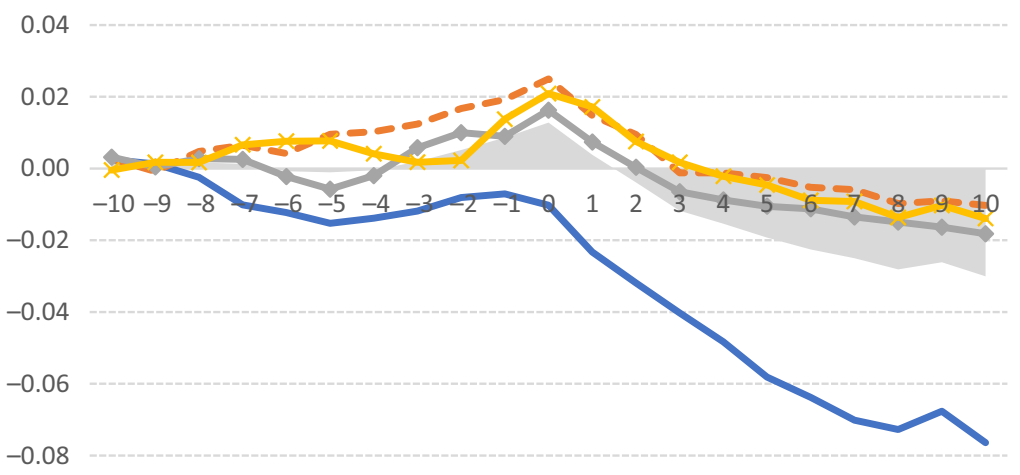

$-0.10$

behaviour is the opposite for large issues. The major portion of the announcement gains vanishes after ten days of the split. Bonus issue events generally seem like a price bubble rather than a future growth signal in the short run when the complete process is considered. Thus, the findings are consistent with the assertation of Baker and Phillips (1993).

\subsection{Comparison of sectoral belonging}

The purpose of this section is to test whether industrial belonging has an impact on market reaction during bonus issue announcements. Industries are grouped into two, which are nonfinancial and financial. Fxplus and Thomson Reuters Eikon databases are used to create the sectoral classification for firms in BIST. Panel $\mathrm{E}$ of Table 1 describes the number of issues for each sub-sector and gives the total amount for non-financial and financial groups. Event study is performed for these groups to examine if market reaction changes according to sectoral belonging. Figure 11 provides a visual comparison for abnormal return behaviour around the announcement days for non-financial and financial groups. Here, there are two points to emphasise. The first one is that the magnitude of market reaction for non-financial

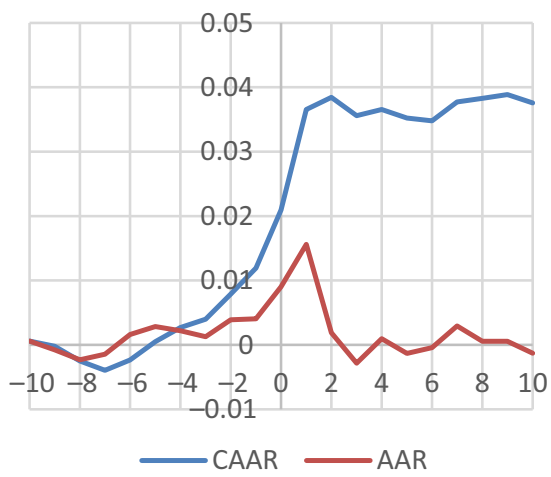

Panel A: Non-financial firms

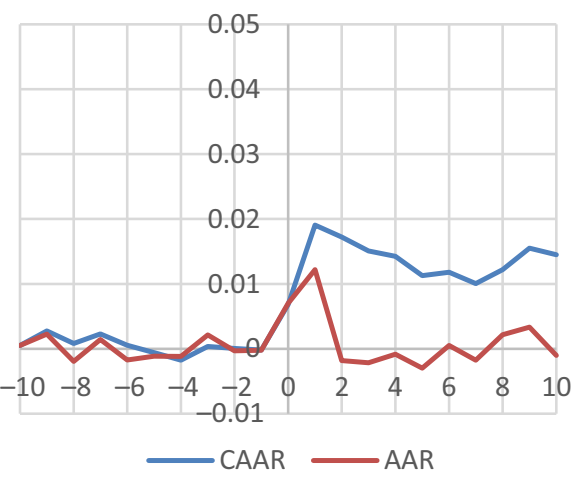

Panel B: Financial firms
Figure 11 . sectoral groups 
firms is higher than financial firms. This finding is in line with Balachandran and Tanner (2001), who examine the Australian market. Second, pre-announcement anomaly is not seen for financial firms, which is not the case for non-financials. A possible reason for the absence of information leakage is that regulations on financial firms are stricter than the non-financial sector, as suggested by Mateus et al. (2017). Also, these firms might have better corporate governance than most non-financial companies. Thus, single-day AARs seem smoother for the financial group.

The market reaction for both groups is statistically tested. Findings in Table 9 suggest that market reaction for financial firms is found insignificant for all event windows. The post-announcement effect for financial firms is weak since the sign test results do not support the existence of an anomaly. Nonetheless, the impact of the bonus issue event for non-financial firms is more visible. To be more precise, for both pre-announcement windows, CAARs are significant, which is a possible sign of information leakage. Moreover, CAAR continues to increase until day two. CAAR is found close to $3.5 \%$ under $(-2,2)$ at the $1 \%$ significance level.

As applied in earlier sections, the independent two-sample $t$-test is conducted to test the impact of sectoral division on market reaction. Panel $\mathrm{C}$ in Table 3 provides Welch $t$-test results since the equal variance assumption of samples is violated. However, event study results give insight regarding the relationship among these groups and do not provide enough evidence to conclude that CAAR for non-financial and financial groups are statistically different from each other. A possible explanation for this result is that anomaly for non-financial group starts before the event. Thus, the lion's share of the anomaly is attributed to the pre-announcement period. Most likely, the difference in market anomaly for financial and non-financial firms is not detected as $(0,2)$ event window is preferred for pairwise comparison.

\subsection{The effect of market sentiment}

Market trends may affect investors' attitude towards corporate events. A bullish (bearish) market condition can boost (worsen) stock returns if there is company-specific positive (negative) news as long as the existing trend persists. This section aims to investigate the impact of market sentiment on investor's perception around bonus issue announcements. First, the dataset is divided into two categories as "bullish" and "bearish" groups. Definition of bullish and bearish markets is adopted from Chua et al. (1987), stated in equation 9. The authors describe a bullish market condition if the return of the market portfolio $\left(R_{M}\right)$ exceeds treasury bond's daily yield $\left(R_{f}\right)$. The same applies to a bearish market if the market portfolio

\begin{tabular}{|c|c|c|c|c|c|c|}
\hline Event windows & Groups & CAAR $(\%)$ & Pos/Neg & Cross-sec & Sign $t$ & \\
\hline \multirow[t]{2}{*}{$(-5,5)$} & Non-fin & 3.76 & $107 / 81$ & $3.023^{* * * *}$ & $2.215^{* *}$ & \\
\hline & Fin & 1.07 & $79 / 76$ & 1.288 & 0.990 & \\
\hline \multirow[t]{2}{*}{$(-2,2)$} & Non-fin & 3.45 & $111 / 77$ & $4.081^{* * *}$ & $2.799^{* * * * *}$ & \\
\hline & Fin & 1.69 & $83 / 72$ & $2.523^{* *}$ & 1.634 & \\
\hline \multirow[t]{2}{*}{$(0,5)$} & Non-fin & 2.33 & $98 / 90$ & $2.155^{* *}$ & 0.902 & \\
\hline & Fin & 1.15 & $81 / 74$ & $1.773^{*}$ & $\begin{array}{l}0.312 \\
1.312\end{array}$ & \\
\hline \multirow[t]{2}{*}{$(0,2)$} & Non-fin & 2.65 & $104 / 84$ & $3.279^{* * * *}$ & $1.778^{*}$ & \\
\hline & Fin & 1.74 & $83 / 72$ & $3.270^{* * * *}$ & 1.634 & \\
\hline \multirow[t]{2}{*}{$(-5,-1)$} & Non-fin & 1.43 & $107 / 81$ & $3.268^{* * * *}$ & $2.215^{* *}$ & \\
\hline & Fin & -0.07 & $74 / 81$ & -0.177 & 0.185 & Table 9. \\
\hline \multirow[t]{2}{*}{$(-2,-1)$} & Non-fin & 0.79 & $115 / 73$ & $3.418^{* * *}$ & $3.383^{* * * *}$ & Event study results for \\
\hline & Fin & -0.05 & $73 / 82$ & -0.195 & 0.024 & sectoral groups \\
\hline
\end{tabular}

Cracking the fault line in stock markets 
JCMS

5,1

90

return is less than the bond yield. In this case, since $(0,2)$ event window is analysed for pairwise comparisons, the cumulative abnormal return of each event is compared with the three-day cumulative bond yield. In this study, $R_{f}$ is the daily yield for Turkey's two-year government bond. Data for bond yield are retrieved from the Fxplus database.

$$
\text { Event }_{i,(0,2)}=\left\{\begin{array}{l}
\text { Bullish, } \\
\text { Bearish, } \sum_{t_{1}=0}^{t_{2}=2} R_{M} \geq \sum_{t_{1}=0}^{t_{2}=2} R_{f}
\end{array}\right\}
$$

After determining the bullish and bearish groups, CAAR is calculated and statistically tested for each group under $(0,2)$ event window. Last year's net income (DIV) and internal resources (IR) groups are also categorised according to market sentiment classification. The paper aims to understand if market sentiment has an impact within each main source groups. Event study results are given in Table 10 .

First, post-event abnormal returns are compared for the pooled data under bullish and bearish market conditions. Although the magnitude of the anomalies is similar, when there is a bullish market condition, the market reaction to the bonus issue announcement is weak since the sign test is insignificant. Second, the impact of market sentiment is examined when DIV is used as a source of the issue. For both groups, the three-day market reaction is calculated close to zero. Finally, the same process is followed for the IR group. Both cases are found highly significant. However, CAAR under the bullish condition for the IR group is slightly higher than the bearish market condition.

The mean difference of cumulative abnormal returns is tested for announcements made under bullish and bearish market conditions. Panel D of Table 3 represents the student's $t$-test results, which compares two independent samples. There is no difference between CAARs for bonus issue announcements during bullish and bearish market conditions. The study concludes that market sentiment does not affect return anomaly after the bonus issue announcement. The mean difference is not tested for DIV and IR groups according to market sentiment since similar results are expected. However, all groups are visually compared from a wider perspective by using $(-10,10)$ event window. Figure 12 shows that CAAR for 21 days is always higher when the bullish market condition is the case. Thus, as a policy recommendation for the managers, it is better to announce a bonus issue when market sentiment is positive regardless of which main source group will be used.

\subsection{The effect of expected and surprise announcements}

Companies listed in BIST generally announce the board's decision regarding profit distribution of last year's income after their annual financial report become publicly available. Mostly, the board's decision cannot be valid unless it is approved in the general meeting. These meetings are usually held in April and May. Also, companies start to announce their annual financial reports by early February until mid of March. Thus, shareholders may expect to hear a capital increase announcement via bonus issue during these months. The dataset is divided into two to examine whether timing of the announcement affects the

Table 10.

Event study results for market sentiment groups

\begin{tabular}{lcccccc}
\hline & ALL_Bullish & ALL_Bearish & DIV_Bullish & DIV_Bearish & IR_Bullish & IR_Bearish \\
\hline CAAR $(0,2)$ & $2.13 \%$ & $2.36 \%$ & $0.03 \%$ & $0.07 \%$ & $3.76 \%$ & $3.61 \%$ \\
Cross-sec & $3.023^{* * *}$ & $3.258^{* * *}$ & 0.066 & 1.385 & $3.238^{* * * *}$ & $3.014^{* * * *}$ \\
Sign & 0.859 & $2.604^{* * * *}$ & -1.1847 & 0.3475 & $2.188^{* * *}$ & $3.150^{* * * *}$ \\
$N$ & 181 & 162 & 79 & 70 & 102 & 92 \\
\hline
\end{tabular}




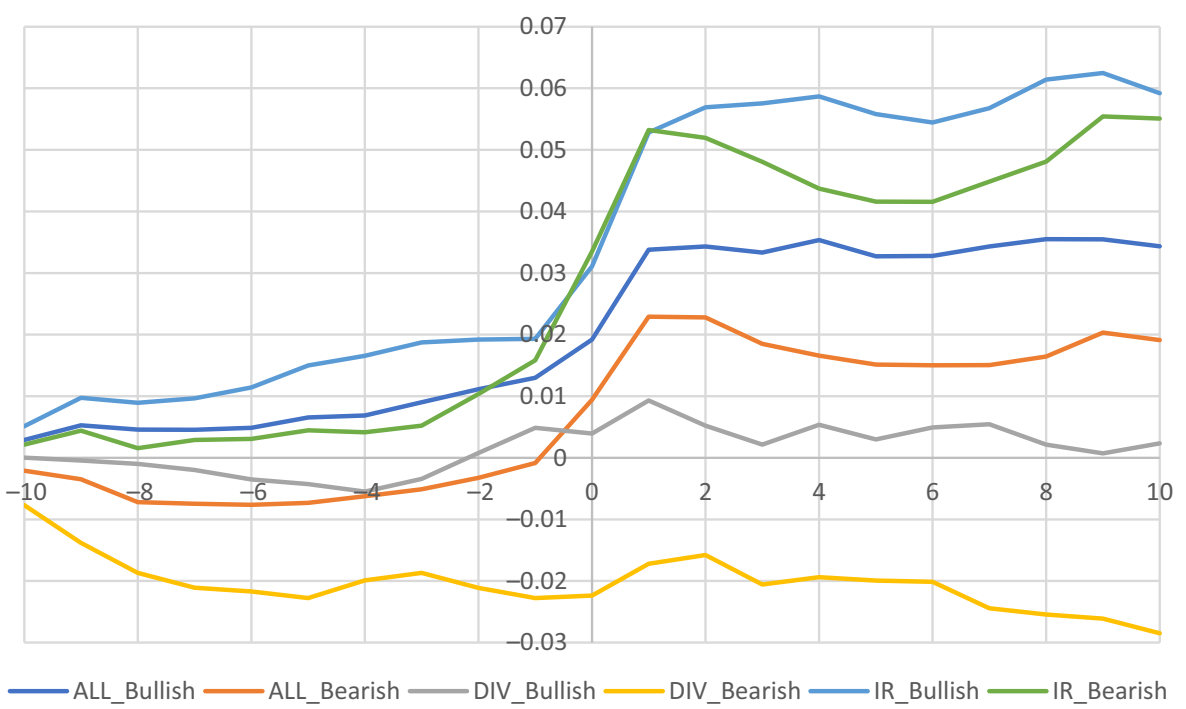

Cracking the fault line in stock markets

market reaction. If a bonus issue announcement belongs to one of these months, it is categorised under the "expected" group. The hand-collected data suggest that $76 \%$ of the bonus issue announcements are released in these months. Contrarily, if an announcement is realised in any of the remaining months (from June to next year's January), it is recorded in the "surprise" group. The number of announcements within this group is 80 out of 343 .

The paper examines whether market reaction differs when bonus issue announcements are expected or not. Welch's $t$-test compares the CAARs for expected and surprise groups. The results are given in Panel E of Table 3. Although market reaction for the surprise group is higher (about $2 \%$ ) than the expected group, test results are insignificant. However, managers may prefer to inform the market participants regarding the bonus issue within unexpected months to maximise the short-term wealth of their shareholder's.

\subsection{Does multiple bonus issues matter?}

Finally, the market reaction of the announcements to the initial and latter bonus issues is compared. During the study period, 168 unique firms are detected, which increase their capital via bonus issue. A total of 106 of these firms apply only once, 26 firms twice, 10 firms three times, 8 firms four times and finally, 18 firms five or more times. The maximum number of bonus issues during the analysis period is found as nine. This means that some firms in BIST frequently (almost every year) distribute bonus shares.

The data are divided into two as "initial" and "latter". For the initial group, announcements for the one-time issuers and the first issues of the multiple issuers are included. For the latter group, the announcements except for initial issues of the multiple issuers are included. The number of announcements for the initial and latter groups is found as 167 and 176, respectively. Two independent sample $t$-test is conducted to compare the market reaction of these groups. Panel F of Table 3 provides Welch's $t$-test results since the homogeneity of variances assumption does not hold. CAARs are found as 4.5 and $0.08 \%$ under $(0,2)$ event window for the initial and latter groups, respectively, while the mean difference is statistically significant at the $1 \%$ level. It seems the latter bonus issues do not impress investors compared to the initial ones. An announcement for the latter issues possibly becomes ordinary news for 
JCMS 5,1

\section{2}

the investors in BIST. This argument is supported by the SD of abnormal returns for these groups. The volatility of abnormal returns for the initial group is much higher than the latter group. Thus, a higher market anomaly can be observed when a firm announces a bonus issue for the first time. Also, a possible explanation is that when a company frequently applies bonus issue, it is more likely to announce smaller sized issues since resources are not cumulated but rather distributed more frequently.

\section{Conclusion and implications}

In theory, bonus issue events are cosmetic amendments and do not affect a firm's value. However, investor's perception towards these events seems nothing but a herding behaviour or irrationality. Findings suggest that market participants seem to create a price bubble, especially when the issue size is large. As suggested by previous studies, huge return variations still can be observed in BIST when a firm announces a bonus issue for capital increase. This can be associated with the absence of a strong form of market efficiency for Borsa Istanbul in the sense of bonus issue events, although over 30 years have passed since its establishment. This paper provides empirical evidence with the current data regarding this case by analysing the information content of the bonus issue announcement.

Event-induced anomaly is detected as well as pre-event abnormal returns in some cases, which is a sign of information leakage and hence the failure of the market efficiency. The paper's findings also suggest that investors behave differently when internal resources are preferred as the main source of a bonus issue instead of last year's net income. A possible explanation for this behaviour is that the accounts of internal resources are accumulated over the years without being distributed to the investors. As bonus issues are perceived as favourable news in general, investors' expectations increase over the years by the accumulation of internal resources. This behaviour seems like accumulating stress (i.e. information content) on a "fault line", and when a bonus issue announcement is released, it causes an "earthquake" (i.e. huge price movements). Findings show that investors perceive larger issues as more favourable, while the subsequent bonus issues become no longer attractive. For the sectoral division, there are two points to highlight. First, a positive market reaction is higher for non-financial firms. Second, financial firms have better corporate governance in the sense of preventing information leakage, unlike non-financial firms. More precisely, a pre-event anomaly is not seen for companies in the financial sector.

Last but not least, although the inflation rate in Turkey has improved significantly compared to the past, it seems that past inflation continues to affect stock returns via bonus issue announcements. The paper documents that the highest abnormal returns are observed when inflation adjustment on equity is used as the main source of a bonus issue. This implies that the effect of high inflation periods is still embedded in firms' financials and indirectly damage the market efficiency.

Policy recommendations arising from the paper's findings represented as follows: first, an upper limit for the bonus distribution rate should be applied. According to the findings, the upper limit should not exceed $75 \%$. The regulatory body will ensure to experience more frequent bonus issues from the firms listed in BIST. Hence, firms who apply frequent bonus issues will not be able to distribute bonus shares in large sizes in the long run, which will help to reduce the market anomaly and hence will help to increase the market efficiency level. Second, investors transactions before the announcement should be examined to understand whether an insider activity exists or not for the firms that show pre-event anomaly. Third, companies that still have inflation adjustments on equity may be asked to primarily use this account during the bonus issues to eliminate its effect in the long run. Fourth, investors or portfolio managers, who hold the shares of a bonus issuing company before the announcement, can generally maximise their returns by selling those shares after two 
days of the event. Investors who would like to open a new long position after the second day should apply a stop-loss strategy to minimise a possible loss.

\section{Notes}

1. Other terms that are used for bonus issue are bonus distribution, bonus dividend and stock dividend. Scrip issue, scrip dividend, or optional stock dividend terms are commonly used in the UK and France. Feito-Ruiz et al. (2020) define scrip dividends as the right to choose between the cash dividend and bonus shares. Stock splits differ from the bonus issues since splits do not affect capital reserve accounts in the equity statement. Also, par value does not change in bonus issue while it is not the case for stock splits.

2. Ten days cumulative return is detected as 28 and $37 \%$ for Ege Endustri AS (EGEEN) and Konya Cimento AS (KONYA), respectively, while the BIST100 index fell by $5 \%$ for the same period.

\section{References}

Adaoglu, C. and Lasfer, M. (2011), "Why do companies pay stock dividends? The case of bonus distributions in an inflationary environment", Journal of Business Finance and Accounting, Vol. 38 Nos 5-6, pp. 601-627.

Al-Yahyaee, K.H. (2014), "Shareholder wealth effects of stock dividends in a unique environment", Journal of International Financial Markets, Institutions and Money, Vol. 28, pp. 66-81.

Anderson, H.D., Chi, J., Ing-aram, C. and Liang, L. (2011), "Stock dividend puzzles in China”, Journal of the Asia Pacific Economy, Vol. 16 No. 3, pp. 422-447.

Aydogan, K. and Muradoglu, G. (1998), "Do markets learn from experience? Price reaction to stock dividends in the Turkish market", Applied Financial Economics, Vol. 8 No. 1, pp. 41-49.

Baker, H.K. and Phillips, A.L. (1993), "Why companies issue stock dividends", Financial Practice and Education, Vol. 3 No. 2, pp. 29-37.

Balachandran, B. and Tanner, S. (2001), "Bonus share issues and announcement effect: Australian evidence", available at SSRN 288743, doi: 10.2139/ssrn.288743.

Balachandran, B., Faff, R., Theobald, M. and Van Zijl, T. (2012), "Rights offerings, subscription period, shareholder takeup, and liquidity", Journal of Financial and Quantitative Analysis, Vol. 47 No. 1, pp. 213-239.

Barnes, M.L. and Ma, S. (2002), "The behavior of China's stock prices in response to the proposal and approval of bonus issues", available at SSRN, doi: 10.2139/ssrn.458541.

Batchelor, R. and Orakcioglu, I. (2003), "Event-related GARCH: the impact of stock dividends in Turkey", Applied Financial Economics, Vol. 13 No. 4, pp. 295-307.

Bechmann, K.L. and Raaballe, J. (2007), "The differences between stock splits and stock dividends: evidence on the retained earnings hypothesis", Journal of Business Finance and Accounting, Vol. 34 Nos 3-4, pp. 574-604, doi: 10.1111/j.1468-5957.2007.02041.x.

Campbell, K. and Ohuocha, C. (2011), "The stock market reaction to stock dividends in Nigeria and their information content", Managerial Finance, Vol. 37 No. 3, pp. 295-311, doi: 10.1108/ 03074351111113333.

Campbell, J.Y., Lo, A.W., MacKinlay, A.C. and Whitelaw, R.F. (1998), "The econometrics of financial markets", Macroeconomic Dynamics, Vol. 2 No. 4, pp. 559-562.

Chua, J.H., Woodward, R.S. and To, E.C. (1987), "Potential gains from stock market timing in Canada", Financial Analysts Journal, Vol. 43 No. 5, pp. 50-56.

Cowan, A.R. (1992), "Nonparametric event study tests", Review of Quantitative Finance and Accounting, Vol. 2 No. 4, pp. 343-358.

David, T. and Ginglinger, E. (2016), "When cutting dividends is not bad news: the case of optional stock dividends", Journal of Corporate Finance, Vol. 40, pp. 174-191. 
JCMS 5,1

\section{4}

Dhar, S. and Chhaochharia, S. (2008), "Market reaction around the stock splits and bonus issues: some Indian evidence", SSRN Working Paper, available at SSRN, doi: 10.2139/ssrn.1087200.

El Ansary, O. and Hussien, M. (2017), "The impact of stock dividends and stock splits on shares' prices: evidence from Egypt", Accounting and Finance Research, Vol. 6 No. 4, pp. 84-96.

Fama, E.F. (1970), "Efficient capital markets: a review of theory and empirical work", The Journal of Finance, Vol. 25 No. 2, pp. 383-417.

Feito-Ruiz, I., Renneboog, L. and Vansteenkiste, C. (2020), "Elective stock and scrip dividends", Journal of Corporate Finance, Vol. 64, p. 101660, doi: 10.1016/j.jcorpfin.2020.101660.

Frunza, M.C. (2016), Solving Modern Crime in Financial Markets: Analytics and Case Studies, Academic Press, Waltham, MA.

Grinblatt, M.S., Masulis, R.W. and Titman, S. (1984), "The valuation effects of stock splits and stock dividends", Journal of Financial Economics, Vol. 13 No. 4, pp. 461-490.

Huang, G.C., Liano, K. and Pan, M.S. (2009), "The information content of stock splits", Journal of Empirical Finance, Vol. 16 No. 4, pp. 557-567.

Isiker, M. and Tas, O. (2021a), "Does leverage level matter for return anomaly during rights issue announcements? The case of Islamic countries", Islamic Economic Studies, Vol. ahead-of-print No. ahead-of-print, doi: 10.1108/IES-07-2020-0023.

Kalay, A. and Zhang, F. (2019), "Vanishing stock dividends", SSRN Working Paper, available at: http://ssrn.com/abstract $=2722115$.

Kato, H.K. and Tsay, W. (2002), “Are stock dividends (MUSHOs) melons or lemons in Japan?”, PacificBasin Finance Journal, Vol. 10 No. 5, pp. 531-548.

Khanal, A.R. and Mishra, A.K. (2017), "Stock price reactions to stock dividend announcements: a case from a sluggish economic period", The North American Journal of Economics and Finance, Vol. 42, pp. 338-345.

Kim, J.H. and Song, K. (2020), “The choice of SEO method in Korea: rights vs. public offers”, Journal of Financial Markets, Vol. 51, doi: 10.1016/j.finmar.2020.100532.

Kolari, J.W. and Pynnonen, S. (2011), "Nonparametric rank tests for event studies", Journal of Empirical Finance, Vol. 18 No. 5, pp. 953-971.

Kothari, S.P. and Warner, J.B. (2007), "Econometrics of event studies", in Eckbo, B.E. (Ed.), Handbook of Empirical Corporate Finance, North Holland, Amsterdam, pp. 3-36.

Lakonishok, J. and Lev, B. (1987), "Stock splits and stock dividends: why, who and when”, Journal of Finance, Vol. 42 No. 4, pp. 913-933.

Lukose, J. and Sapar, N.R. (2002), "Does bonus issue signal superior profitability? A study of the BSE listed firms", (December 2002), available at: https://ssrn.com/abstract $=428122$.

MacKinlay, A.C. (1997), "Event studies in economics and finance", Journal of Economic Literature, Vol. 35 No. 1, pp. 13-39.

Mateus, C., Farinha, J. and Soares, N. (2017), "Price discounts in rights issues: why do managers insist on what investors hate?", European Business Review, Vol. 29 No. 4, pp. 457-475.

McNichols, M. and Dravid, A. (1990), "Stock dividends, stock splits, and signaling", The Journal of Finance, Vol. 45 No. 3, pp. 857-879.

Mian, G.M. and Sankaraguruswamy, S. (2012), "Investor sentiment and stock market response to earnings news", The Accounting Review, Vol. 87 No. 4, pp. 1357-1384.

Nguyen, N.H. and Wang, D.Y. (2013), "Stock dividends in China: signalling or liquidity explanations?”, Accounting and Finance, Vol. 53, pp. 513-535.

Pathirawasam, C. (2009), "The information content of stock dividend announcements: evidence from Sri Lanka”, Central European Review of Economic Issue, Vol. 12, pp. 103-114, doi: 10.7327/cerei. 2009.09.01. 
Raja, M. and Sudhahar, J.C. (2010), "An empirical test of Indian stock market efficiency in respect of bonus announcement”, Asia Pacific Journal of Finance and Banking Research, Vol. 4 No. 4, pp. 1-14.

Rankine, G. and Stice, E.K. (1997), "The market reaction to the choice of accounting method for stock splits and large stock dividends", Journal of Financial and Quantitative Analysis, Vol. 32 No. 2, pp. 161-182.

Ruxton, G.D. (2006), "The unequal variance t-test is an underused alternative to Student's t-test and the Mann-Whitney U test", Behavioral Ecology, Vol. 17 No. 4, pp. 688-690.

Schultz, P. (2000), "Stock splits, tick size, and sponsorship", The Journal of Finance, Vol. 55 No. 1, pp. $429-450$.

Wulff, C. (2002), "The market reaction to stock splits-evidence from Germany", Schmalenbach Business Review, Vol. 54 No. 3, pp. 270-297.

\section{Further reading}

Deloitte (2021), "Financial reporting in hyperinflationary economies", available at: https:/www. iasplus.com/en/standards/ias/ias29 (accessed 6 February 2021).

Isiker, M. and Tas, O. (2021b), "Motives behind the return anomaly around bonus issue announcements: the case of emerging markets", Review of Behavioral Finance, Vol. ahead-ofprint No. ahead-of-print, doi: 10.1108/RBF-05-2020-0092.

Istanbul Chamber of Certified Public Accountants (2021), "Tekdüzen hesap çerçevesi”, available at: https://www.ismmmo.org.tr/dosya/415/Mevzuat-Dosya/tekduzhesapplani.pdf (accessed 6 February 2021).

\section{Corresponding author}

Murat Isiker can be contacted at: isikermurat@hotmail.com

For instructions on how to order reprints of this article, please visit our website: 